\title{
Waste tea as a novel adsorbent: a review
}

\author{
Siam Hussain $^{1}$ [D K. P. Anjali ${ }^{1}$ Saima Towhida Hassan ${ }^{1} \cdot$ Priy Brat Dwivedi $^{1}$
}

Received: 26 February 2018 / Accepted: 13 September 2018 / Published online: 20 September 2018 (c) The Author(s) 2018

\begin{abstract}
This paper surveys the various developments in the usage of tea beverage industry-based wastes for adsorption and the generation of activated carbon while emphasizing the applied methodology, removal efficiencies, characteristics of the material and the production methods. From the review, it can be determined that the tea industry-based wastes offer a promising, low-cost and effective alternative adsorbent for the removal of various effluents from the water. The full review is about the usage of waste tea as an adsorbent has been done while considering two aspects. Firstly, initial emphasis was placed on reviewing the research work on the removal of various heavy metal ions and pollutants such as copper, chromium, lead, reactive dyes and phenols using tea leaves as an adsorbent. Secondly, research work on the various activation methods and conditions, and the usage of physical and chemical activating agents such as steam, carbon dioxide, phosphoric acid, zinc chloride and potassium salts for the activation of tea leave-based activated carbon have been reviewed and presented here.
\end{abstract}

Keywords Activated carbon · Adsorption · Bio-adsorbents $\cdot$ Wastewater treatment $\cdot$ Waste tea leaves

\section{Introduction}

The rise of industrialization has been of great economic benefit around the world, but unfortunately, it has come with a firm price. Reckless and unchecked growth has resulted in detrimental consequences where we increasingly find our natural resources being polluted to levels beyond imaginable. Water being the elixir of life; its contamination is of particular concern. The hydrosphere is being increasingly contaminated by growing levels of organic and inorganic industrial effluents including heavy metals such as chromium and copper, waste acids and bases, phenols and oils. A significant number of the effluents found in wastewater cannot be degraded nor destroyed. While a number of techniques such as evaporation, ion-ion exchange, reverse osmosis, membrane-based solvent extraction, destruction by catalytic wet air oxidation (Bhargava et al. 2006), photocatalytic oxidation, membrane pervaporation, (Kondo and Sato 1994) precipitation have been devised for the treatment of wastewater, the disadvantages allied with these methods

\footnotetext{
K. P. Anjali

kpanjali@gmail.com

1 Department of Mechanical and Industrial Engineering, Caledonian College of Engineering, P.O. Box: 2322,

111 CPO Seeb, Sultanate of Oman
}

cannot be ignored. Adsorption, on the other hand, has been considered a comparatively efficient method and has been used extensively for the removal of organic and inorganic micropollutants from wastewater.

However, the production of commercially available activated carbon that is widely used for adsorptive purposes entails high manufacturing costs (Ajmal et al. 2005; Ahmad and Hameed 2009; Mahvi 2009; Pajooheshfar and Saeedi 2009; Demiral and Gündüzog 2010). The precursor materials such as coal, wood and coconut shells that are widely used for the production of activated carbon are expensive and often need to be imported (Baccar et al. 2009). As a result, several studies have been undertaken that investigated the potential of using agricultural and household wastes such as olive stones (Shalaby et al. 2006; Ubago-Pérez et al. 2006; Kula et al. 2008), spent grains (Li et al. 2010), rice husks (Khan et al. 2010), almond shells (Plaza et al. 2010), herb residues (Yang and Qiu 2011), cotton stalks (Deng et al. 2009), bamboo (Ahmad and Hameed 2009), macadamia nutshells (Ahmadpour and Do 1997), durian shells (Chandra et al. 2009), giant reeds (Yue et al. 2010) and coffee husks (Oliveira et al. 2009) as AC precursors for the treatment of wastewater. Furthermore in recent times, the usage of dead biomass such as fertilizer husk (Srivastava et al. 1997), rice husks (Srinivasan et al. 1988), mustard oil cake (Ajmal et al. 2005), green algae (Nuhoglu et al. 2002; Malkoç and 
Nuhoglu 2003), pine bark and almond shell (Rossner and Snyder 2009) for the removal of pollutants from wastewater has shown increasing promise. One particular area of interest revolved around the usage of waste tea leaves for the adsorptive purposes due to the comparatively easier availability. Tea is obtained from the leaves of the Camellia sinensis $L$ Camellia assamica and Cambodiensis plants (Kazmi et al. 2013). Although there exists a wide variety of tea in the commercial realm, those derived from the leaves of the plants mentioned above can be divided into six main categories: black, oolong, green, white, pure and dark. The differences among the varieties arise from the variations in the withering and oxidation processes.

Several studies have evaluated the usage of waste tea leaves (Khosla et al. 2011; Cheraghi et al. 2015) or tea factory wastes (Wasewar et al. 2008) or factory-rejected tea (Nasuha and Hameed 2011a, b) as an adsorbent for the removal of effluents from water. Composition wise, black tea consists of the cell wall material, hot water soluble polysaccharides and proteins along with hot water insoluble proteins, lignin, a structural protein and cellulose (Tan 1985). The insoluble cell walls themselves contain cellulose, hemicellulose, lignin and condensed tannins (Thapak et al. 2015). About 3\% of the dry weight of tea is constituted by caffeine which translates to somewhere between 30 to $90 \mathrm{mg}$ per $250 \mathrm{ml}$ cup depending on the type of tea and the brewing method. Polyphenols such as flavonoids and epigallocatechin gallate are the most abundant compounds in tea leaves, and they constitute about 30-40\% of its dry weight. These compounds contribute to the astringency found in tea beverages (Chatterjee et al. 2012). A minuscule amount of theobromine and theophylline are also found in tea leaves (Harbowy et al. 1997). In a physical sense, tea possesses the properties of a suspension and solution as well, i.e., it is a solution that contains all the water soluble compounds such as the polyphenols and amino acids while at the same time being a suspension resulting from the presence of insoluble components such as cellulose and lignin (Troup et al. 2015). The percentage composition of insoluble material present in black tea is shown in Table 1.

It is without a doubt that the tea is the most popular and widely consumed beverage that is consumed around the world. The consumption of tea alone equals that of coffee, chocolate, soft drinks and alcohol combined (Macfarlane and Macfarlane 2011). It has been estimated that around the world somewhere between 18 to 20 billion cups of tea are drunk on a daily basis. The prosperity of the tea beverage industry in China has resulted in it being accountable for over $20 \%$ of the domestic beverage market alone. Such a staggering level of consumption brings forth with the issues regarding the safe disposal of the tea leaves as about $90 \%$ of the tea is left behind post-extraction and consumption (Auta and Hameed 2011b; Peng et al. 2013). The issues do
Table 1 Percentage composition of ethanol insoluble material of black tea (dry weight basis) (Harler 1963)

\begin{tabular}{lc}
\hline Constituent & Percentage \\
\hline Cell wall material & 46.8 \\
Hot water soluble polysaccharide and proteins & 9.6 \\
Hot water insoluble proteins & 12.1 \\
Lignin and structural proteins & 14.7 \\
Cellulose & 37.2 \\
\hline
\end{tabular}

not stop with the waste generated post-consumption as the manufacturing process also contributes to the amount of tea-based organic wastes. It has been reported that about 30,000 tons of tea factory waste in Turkey are disposed of in the small bays surrounding Black Sea (Malkoç and Nuhoglu 2003; Yagmur et al. 2008). The factory-rejected tea that is generated mainly during the withering process of production alone amounted to 100,000 tons per annum in Malaysia (Nasuha and Hameed 2011a, b). The annual production of about 857,000 tons of tea in India results in the generation of about 190,000 tons of tea factory waste (Wasewar et al. 2008). Furthermore, the rising popularity of tea seed oil results in the generation of over a million tons of tea seed shells as agro-industrial wastes in China alone (Gao et al. 2013). It is quite evident that the generation of such massive quantities of wastes from the tea industry alone will undoubtedly result in a host of environmental problems associated with their improper disposal. Furthermore, the lack of sustainable waste management practices concerning tea industry wastes exacerbates the issue further. Waste tea leaves and the factory generated tea wastes can be classified as carbonaceous adsorbents. Their physiochemical characteristics such as large surface capacity and the fast kinetics of adsorption make it suitable low-cost adsorbent for the removal of effluents from wastewater and also as an inexpensive precursor material for the production of activated carbon.

This paper focuses its attention on the review and evaluation of the literature that focuses on the usage of tea-based organic material as an adsorbent for the removal of various effluents from wastewater with or without carbonization while summarizing various aspects such as methodology, adsorption mechanisms, results of characterization studies and effluent removal efficiencies.

\section{Adsorption using waste tea}

\section{Material pre-treatment}

Before the actual usage of waste tea leaves or tea factory waste either as an adsorbent or a precursor for the production 
of activated carbon, it needs to undergo few preliminary stages such as milling, sieving and washing. Washing plays an essential role in the pre-treatment process as tea-based wastes contain considerable amounts of hydrolyzable tannins, polysaccharides and proteins along with other soluble and colored components which need to be eliminated before being used to avoid undue contamination. The usage of hot distilled water to wash the raw material several times until the supernatant solution remained colorless, was a technique shared among several studies. Wasewar et al. (2008) and Cay et al. (2004) reported that the usage of hot dilute solutions of $\mathrm{NaOH}$ for washing the raw material reduced the number of washing cycles required. Particle size plays a vital role in the handling of the raw material when it comes to mixing with a catalyst or impregnation and can also affect the properties of the subsequent AC. Malakahmad et al. (2016) reported that the particle size distribution determined the surface area of the adsorbent and smaller particle size account for larger surface area available for adsorption. Few researchers used the raw material in the original form, whereas others either milled or sieved the raw material to a particle size below $300 \mu \mathrm{m}$. The adsorbents were always oven-dried before the usage.

\section{Waste tea as an adsorbent}

About one-third of the net dry matter in tea leaves contains mainly carboxylate, aromatic, phenolic, hydroxyl and oxyl groups. This composition is responsible for its ion-exchange behavior (Ahmaruzzaman and Gayatri 2010) which in turn improves its potential to be used as a metal scavenger from solutions and wastewaters. The EDS curve of tea wastes as shown in Fig. 1 revealed the presence of a high concentration of elements found in commercial activated carbon such as carbon and calcium that allowed waste tea to demonstrate a high adsorption capacity (Matta et al. 2008).

\section{Removal of copper and chromium ions}

The efficiency of tea waste in removing heavy metals from synthetic wastewater was studied by Kumar et al. (2015). Sulfuric acid of $1.0 \mathrm{M}$ was used to chemically activate the tea waste sample. The effect of contact time, $\mathrm{pH}$ and adsorbent dose on the percentage removal of heavy metals, copper and chromium was evaluated through spectrophotometric analysis of the concentration of the metals in residue at $312 \mathrm{~nm}$ and $540 \mathrm{~nm}$. The experiment revealed maximum removal percentage of the metals to be $91 \%$ and $94 \%$ for copper and chromium at their respective optimum conditions as indicated in Table 2. A similar study done by Thapak et al. (2015) activated the tea wastes using 1.0 M sulfuric acid and used it to adsorb copper ions from synthetic wastewater. The effect of contact time, $\mathrm{pH}$ and adsorbent dose on

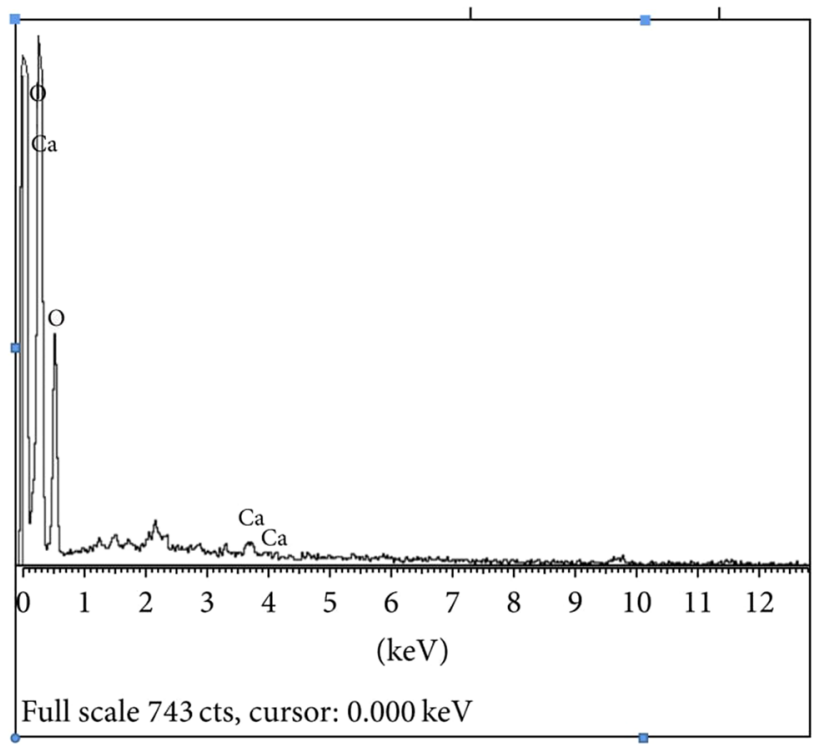

Fig. 1 EDS curve of tea waste (Malakahmad et al. 2016)

the percentage removal of heavy metals was studied, and maximum removal of copper by tea waste calculated to be around $90 \%$ on an average.

Tan (1985), however, focused on evaluating the usage of tea wastes that were physically activated by heating in the oven at $110{ }^{\circ} \mathrm{C}$, as opposed to chemical activation. The batch adsorption experiment involved the addition of specific amounts of activated and non-activated adsorbents separately to a stock solution for a residence time of $4 \mathrm{~h}$ after which the remaining concentration of $\mathrm{Cu}$ (II) was measured. The study evaluated the changes in the $\mathrm{Cu}$ (II) removal efficiency corresponding to an increase in $\mathrm{pH}$ and initial metal ion concentration that revealed that optimal removal occurred at pH 6 and an adsorbent loading of $10 \mathrm{~g}$. It was also observed that an increase in the concentration of foreign ions such as $\mathrm{K}^{+}$and $\mathrm{Pb}^{+}$negatively affected the adsorption of $\mathrm{Cu}$ (II). Provided that the process parameters be kept constant, activated absorbent demonstrated a higher removal efficiency when compared to the non-activated adsorbent.

Jeyaseelan and Gupta (2016) designed this experiment to deal with the efficiency of unmodified waste green tea leaves to remove chromium $[\mathrm{Cr}(\mathrm{VI})]$ ions from aqueous solution of $\mathrm{Cr}(\mathrm{VI})$ concentration $1000 \mathrm{~mL} / \mathrm{L}$ by the batch method. Dried tea waste was agitated at a constant speed with the stock solution until equilibrium was reached followed by concentration of the sample analyzed using UV spectrophotometer at $540 \mathrm{~nm}$. The study revealed the maximum removal efficiency of $\mathrm{Cr}(\mathrm{VI})$ by the adsorbent sample as nearly $99 \%$ for an optimum condition of $2 \mathrm{pH}, 180 \mathrm{~min}$. Contact time and $0.8 \mathrm{~g} / \mathrm{L}$ dosage of adsorbent, as well as the presence of metal ions such as $\mathrm{Zn} 2+$ and $\mathrm{Cd} 2+$ in the stock solution, seem to increase the removal percentage, whereas ions such as $\mathrm{Ni}^{2+}$, 
Table 2 Optimal conditions for the adsorption of various ions/compounds on waste tealeaves

\begin{tabular}{|c|c|c|c|c|c|c|c|}
\hline \multirow[t]{2}{*}{ S. No } & \multirow[t]{2}{*}{ Adsorbate } & \multirow[t]{2}{*}{ Initial concentration } & \multicolumn{5}{|c|}{ Optimal conditions } \\
\hline & & & $\mathrm{pH}$ & $\begin{array}{l}\text { Contact } \\
\text { time }(\mathrm{h})\end{array}$ & Adsorbent dosage (g) & Adsorption capacity & References \\
\hline 1. & p-nitrophenol & $1 \mathrm{~g} / \mathrm{L}$ & 2 & 5 & - & $142.85 \mathrm{mg} / \mathrm{g}$ & $\begin{array}{l}\text { Ahmaruzzaman and Gayatri } \\
\text { (2010) }\end{array}$ \\
\hline \multirow[t]{3}{*}{2.} & \multirow[t]{3}{*}{ Zinc } & - & 4.2 & 0.5 & $0.2 \mathrm{~g} / 50 \mathrm{ml}$ & $14.2 \mathrm{mg} / \mathrm{g}$ & Wasewar et al. (2008) \\
\hline & & $4.40 \mathrm{~g} / \mathrm{L}$ & 5 & 3.1 & $2 \mathrm{~g} / 100 \mathrm{ml}$ & $166.7 \mathrm{mg} / \mathrm{g}$ & Malakahmad(2016) \\
\hline & & $15-105 \mathrm{mg} / \mathrm{L}$ & 1 & 1 & $0.2 / 100 \mathrm{ml}$ & - & Abbas (2014) \\
\hline 3. & Copper & $1 \mathrm{~g} / \mathrm{L}$ & 6 & 2 & $0.6 \mathrm{~g} /{ }^{-}$ & - & Thapak et al. (2015) \\
\hline 4. & Lead & $2 \mathrm{~g} / \mathrm{L}$ & 5.5 & 24 & $0.2 / 50 \mathrm{ml}$ & $83-130 \mathrm{mg} / \mathrm{g}$ & Zuorro and Lavecchia (2010) \\
\hline 5. & Methylene blue & $0.5 \mathrm{~g} / \mathrm{L}$ & 7 & - & $0.5 \mathrm{~g} / 200 \mathrm{ml}$ & $242.11 \mathrm{mg} / \mathrm{g}$ & Islam et al. (2015) \\
\hline 6. & Progesterone & $1 \mathrm{~g} / \mathrm{L}$ & 7 & - & - & $1.8 \mathrm{mg} / \mathrm{g}$ & $\begin{array}{l}\text { Ifelebuegu and Onwugbuta } \\
\text { (2016) }\end{array}$ \\
\hline 7. & Reactive blue 25 dye & $0.1 \mathrm{~g} / \mathrm{L}$ & 6 & 1.5 & $4 \mathrm{~g} / 100 \mathrm{ml}$ & $28.99 \mathrm{mg} / \mathrm{g}$ & Reza et al. (2016) \\
\hline 8. & $17 \beta$-estradiol & $1 \mathrm{~g} / \mathrm{L}$ & 7 & 1 & $1 \mathrm{~g} / 200 \mathrm{ml}$ & $3.46 \mathrm{mg} / \mathrm{g}$ & Ifelebuegu et al. (2015) \\
\hline 9. & $17 \alpha$-ethinylestradiol & $1 \mathrm{~g} / \mathrm{L}$ & 5 & 1 & $1 \mathrm{~g} / 200 \mathrm{ml}$ & $2.44 \mathrm{mg} / \mathrm{g}$ & \\
\hline 10. & Bisphenol A & $1 \mathrm{~g} / \mathrm{L}$ & 7 & 1 & $1 \mathrm{~g} / 200 \mathrm{ml}$ & $18.35 \mathrm{mg} / \mathrm{g}$ & \\
\hline 11. & Chromium (IV) & $5-500 \mathrm{mg} / \mathrm{L}$ & 2 & 3 & $0.8 \mathrm{~g} / 250 \mathrm{ml}$ & - & Jeyaseelan and Gupta (2016) \\
\hline 12. & Malachite green & - & 6 & - & $75 \mathrm{mg} /-$ & $69.7 \mathrm{mg} / \mathrm{g}$ & Jung et al. (2014) \\
\hline \multirow[t]{2}{*}{13.} & \multirow[t]{2}{*}{ Nickel } & $4.05 \mathrm{~g} / \mathrm{L}$ & 5 & 3.1 & $2 \mathrm{~g} / 100 \mathrm{ml}$ & $90.91 \mathrm{mg} / \mathrm{g}$ & Malakahmad et al. (2016) \\
\hline & & $1 \mu \mathrm{g} / \mathrm{mL}$ & 7 & 1.5 & $0.13 \mathrm{~g} / 50 \mathrm{ml}$ & $120.5 \mathrm{mg} / \mathrm{g}$ & Shah et al. (2015) \\
\hline
\end{tabular}

$\mathrm{Cu}^{2+}$ and $\mathrm{Fe}^{2+}$ showed the opposite effect. The adsorption of copper and chromium ions could be better explained using the Freundlich model, while its kinetics best fit the pseudosecond-order model.

\section{Removal of lead ions}

Zuorro and Lavecchia (2010) investigated the lead ions removal efficiency of untreated black and green tea waste and found advantageous over fuller's earth and activated carbon. Batch adsorption experiments involved the addition of $0.2 \mathrm{~g}$ of dried tea leaves to $40 \mathrm{ml}$ of stock solution for $20 \mathrm{~h}$; the results of which revealed a removal efficiency exceeding $95 \%$. Colorimetric analysis of $50 \mathrm{ml}$ of $0.1 \mathrm{~g} / \mathrm{L}$ lead concentration solution after contacting it with $0.5 \mathrm{~g}$ of different adsorbents for $2 \mathrm{~h}$ revealed that at an optimum temperature of $25{ }^{\circ} \mathrm{C}$, black and green tea wastes, respectively, showed better adsorptive properties with adsorption capacities of around $115.4 \mathrm{mg} / \mathrm{g}$ and $83.8 \mathrm{mg} / \mathrm{g}$. Comparison of the experimental data against Langmuir and Freundlich isotherms revealed that the adsorption process could be better explained by the Langmuir model.

Similarly, Cheraghi et al. (2015) assessed the adsorption capacity of waste tea leaves to remove lead [ $\mathrm{Pb}(\mathrm{II})]$ ions from a stock solution. At varying parameters, a certain amount of dried tea leaves were stirred with $100 \mathrm{ml}$ of the aqueous solution for $6 \mathrm{~h}$ at a constant speed of $160 \mathrm{rpm}$ after which the final lead ion concentration was analyzed using inductively coupled mass spectrometer. The tea leaves had humidity, dissolved-material, organic matter and ash content percentages as $10.5,81,85$ and $2.85 \%$, respectively, with density and total solution particle being $0.353 \mathrm{~g} / \mathrm{cm}^{3}$ and $108 \mathrm{mg} / \mathrm{L}$. The study revealed the maximum adsorptive capacity of the tea waste as $166.6 \mathrm{mg} / \mathrm{g}$ which was observed to increase with adsorbent dose and $\mathrm{pH}$ until optimum at $2 \mathrm{~g}$ and $\mathrm{pH}$ six, whereas an increase in temperature and initial metal ion concentration showed reverse effect with optimum temperature being $25^{\circ} \mathrm{C}$. Additionally, the pseudo-secondorder model better described the adsorption kinetics, while the adsorption process could be better explained by the Langmuir model, thereby indicating monolayer adsorption on a homogenous surface.

The effect of varying the adsorbent dosage on the adsorption of lead (II) ions on tea waste was studied by Fauziah et al. (2015). The adsorbent seems to show increasing removal percentage of $87.89,88.33$ and $89.6 \%$ for an adsorbent dose of $0.5 \mathrm{~g}, 1.0 \mathrm{~g}$ and $1.5 \mathrm{~g}$, respectively. The removal percentage also seemed to increase linearly with a contact time of 60 min onwards.

\section{Removal of heavy metal ions}

Orhan and Büyükgüngör (1993) studied the removal of $\mathrm{Cr}(\mathrm{IV}), \mathrm{Cd}(\mathrm{II})$ and $\mathrm{Al}(\mathrm{III})$ metal ions from synthetic wastewater using waste tea, Turkish coffee, exhausted coffee, granular activated carbon, nut and walnut shells as adsorbents. 
The batch adsorption tests determined that equilibrium was reached after $120 \mathrm{~min}$ and could be described as a first-order reversible reaction and the sorption equilibrium data best fit the Freundlich isotherm irrespective of the adsorbent used. Waste tea was determined to have a removal efficiency of 93, 98, and 98\%, respectively, for $\mathrm{Cr}(\mathrm{IV}), \mathrm{Cd}(\mathrm{II})$ and $\mathrm{Al}(\mathrm{III})$ ions as compared to $98.5,99$ and $99.8 \%$, respectively, for granular activated carbon. Furthermore, waste tea's Cd (II) removal efficiency (98\%) was comparatively higher than that of Turkish coffee (70\%), exhausted coffee (89\%), nut (78\%) and walnut shells (90\%), respectively.

Ahluwalia and Goyal (2005) evaluated the efficiency of using biomass of tea leaves to remove heavy metals from aqueous solution at $\mathrm{pH} 5$. Results from batch adsorption test revealed percentage removal of lead $(\mathrm{Pb})$, iron $(\mathrm{Fe})$, zinc $(\mathrm{Zn})$ and nickel $(\mathrm{Ni})$ as 96, 91, 72 and 58\%, respectively. Using the same adsorbent in a multi-metallic mixture having an initial concentration of $92.5 \mathrm{mg} / \mathrm{L}, 21.5 \mathrm{mg} / \mathrm{L}$ and $10 \mathrm{mg} / \mathrm{L}$ of lead, iron and zinc showed removal percentage of $92.5,84$ and $73.2 \%$, respectively. The usage of dried biomass in the adsorption column revealed a sorption capacity of $73 \mathrm{mg}-\mathrm{Pb} / \mathrm{g}$. A similar study by Thakur and Parmar (Thakur and Parmar 2013) investigated the efficiency of untreated tea waste in the removal of heavy metals through batch adsorption at $30{ }^{\circ} \mathrm{C}$. Results from the experiment showed removal percentage of 94,89 and $90 \%$ for nickel $\left(\mathrm{Ni}^{2+}\right)$, copper $\left(\mathrm{Cu}^{2+}\right)$ and zinc $\left(\mathrm{Zn}^{2+}\right)$, respectively, under the optimal condition of $\mathrm{pH} 5,120$ min residence time and an adsorbent dose of $0.5 \mathrm{~g} / 100 \mathrm{ml}$.

The usage of bio-sorbents entails with it the problems related to leaching Shah et al. (2015) used formaldehyde to improve the structural stability of the waste tea leaves. $100 \mathrm{ml}$ of $0.4 \%$ formaldehyde solution was added to every $10 \mathrm{~g}$ of waste tea leaves for $24 \mathrm{~h}$. The resultant adsorbent having a BET surface area of $636.023 \mathrm{~m}^{2} / \mathrm{g}$ was used in batch adsorption experiments where the effects of varying the initial ion concentration, $\mathrm{pH}$ of the solution, temperature, adsorbent dosage and contact time on the percentage removal of $\mathrm{Ni}$ (II) were investigated. The equilibrium data could be best described by the Langmuir adsorption model, and the maximum monolayer sorption capacity was evaluated to be $120.5 \mathrm{mg} / \mathrm{g}$. Optimal sorption of Ni(II) ions was found out at an adsorbent dosage and $\mathrm{pH}$ of $0.13 \mathrm{~g}$ and 7 , respectively. Evaluation of the sorption thermodynamics revealed it to be of spontaneous and exothermic in nature.

Similarly, Malakahmad et al. (2016) characterized and evaluated the efficiency of waste black tea (WBT) as a lowcost adsorbent for the removal of $\mathrm{Ni}^{2+}$ and $\mathrm{Zn}^{2+}$ ions from aqueous solutions. Batch adsorption experiments determined that optimal adsorption of phenol on waste tea leaves occurs at an adsorbent dosage of $20 \mathrm{~g} / \mathrm{L}, \mathrm{pH} 5$ and contact time of 250 min where the maximum capacity of WBT would be $90.91 \mathrm{Mg}-\mathrm{Ni} / \mathrm{g}$ and $166.67 \mathrm{Mg}-\mathrm{Zn} / \mathrm{g}$.

\section{Removal of zinc ions}

Wasewar et al. (2008) investigated the feasibility of using tea waste as an adsorbent for the removal of zinc from wastewater. The characterization studies revealed the tea waste to have a BET surface area of $1.3196 \mathrm{~m}^{2} / \mathrm{g}$ along with a $46.74 \%$ carbon content on a dry basis. The batch adsorption experiments determined that maximum adsorption of $\mathrm{Zn}^{2+}$ ions be $14.2 \mathrm{mg} / \mathrm{g}$ at a pH of 4.2 and temperature of $333 \mathrm{~K}$. The results from the kinetic testing suggested that the adsorption of $\mathrm{Zn}(\mathrm{II})$ closely followed pseudo-second-order kinetics. Although the adsorption pattern followed Freundlich, Langmuir, Tempkin and Redlich-Peterson isotherms at all temperatures, the equilibrium data could be best described by the Freundlich model. The $\Delta \mathrm{H}_{0}$ and the $\Delta \mathrm{S}_{0}$ values for the sorption processes were calculated to be $11.55 \mathrm{~kJ} / \mathrm{mol}$ and $31.24 \mathrm{~kJ} / \mathrm{mol} \mathrm{K}$, respectively, thereby indicating an endothermic and feasible nature of the adsorption process.

Rather than using waste tea leaves in their original form, Abbas (2014) used the residue remaining after the extraction of peroxidase enzymes from it for the adsorption of zinc ions from synthetic wastewater. The batch adsorption experiments evaluated the effects of changes in the initial concentration, agitation speed, adsorbent dosage, contact time and $\mathrm{pH}$ on the amount of zinc ions adsorbed. The results from the experiments revealed that maximum adsorption occurred at $\mathrm{pH} 1$ and adsorbent dosage of $0.1 \mathrm{~g}$. Also, an increase in the agitation speed from 100 to $400 \mathrm{rpm}$ increased the percentage removal of zinc ions, whereas an increase in the initial concentration from 1 to $100 \mathrm{mg} / \mathrm{L}$ resulted in a proportional decrease.

\section{Removal of dyes}

Nasuha and Hameed (2011a, b) used the batch method at equilibrium to study the chemical modification of dried rejected tea by $0.05 \mathrm{M}$ sodium hydroxide to adsorb methylene blue (MB) from its aqueous solution of concentration $1 \mathrm{~g} / \mathrm{L}$. (0.5) $\mathrm{g}$ of adsorbent sample was added to the $200 \mathrm{ml}$ stock solution after which double-beam UV-Vis spectrometer was used to analyze the MB concentration. The experiment result showed economic enhancement in monolayer adsorption capacity to a maximum of around $242.11 \mathrm{mg} / \mathrm{g}$. Furthermore, according to the data collected the adsorption isotherm and kinetics seem to fit into Langmuir and pseudosecond-order models, respectively.

Khosla et al. (2011) investigated the effectiveness of using untreated tea waste (TW) and sodium dodecyl sulfate modified tea waste (SDS-TW) to remove Basic Red 12 (BR-12) dye from its aqueous solution. The maximum adsorption capacity of $97.28 \mathrm{mg} / \mathrm{g}$ and $96.77 \mathrm{mg} / \mathrm{g}$ was shown by TW and SDS-TW under the optimal condition of $5 \mathrm{~g} / \mathrm{L}$ adsorbent dose and $\mathrm{pH} 3$ and $\mathrm{pH} 4$, respectively. The 
adsorption capacity of both adsorbents seemed to increase with an increase in temperature and initial dye concentration. Experimental data revealed the adsorption isotherm and kinetics to fit into Langmuir and pseudo-second-order model, respectively. The thermodynamic evaluation indicated the adsorption to be random, spontaneous and endothermic in nature.

Jung et al. (2014) investigated the efficiency of different spent tea leaves in the removal of Malachite green dye from aqueous solution using batch equilibrium test at room temperature. Through spectrophotometric analysis Peppermint (PM), Decaffeinated Green Tea (DGT), Green Tea (GT) and Chamomile (CM) were found to show maximum monolayer adsorption capacity in decreasing order under optimal conditions. The highest maximum adsorption capacity of $60.7 \mathrm{mg} / \mathrm{g}$ was shown by PM. The adsorption capacity showed a decrease with an increase in salinity and heavy metal effect. Experimental data revealed that the process adsorption capacity, binding affinity and adsorption energy fit into Langmuir, Freundlich and Dubinin-Radushkevich models, respectively.

Reza et al. (2016) studied the effectiveness of using untreated tea waste in the removal of reactive blue (RB21) dye from aqueous solution. The adsorbent showed maximum monolayer adsorption capacity of around $28.99 \mathrm{mg} / \mathrm{g}$ under the optimal condition of the residence time of $90 \mathrm{~min}, \mathrm{pH} 6$ and $4.0 \mathrm{~g} / 100 \mathrm{ml}$ adsorbent dose. The adsorption capacity showed a decrease with an increase in dye concentration from an initial value of $5 \mathrm{mg} / \mathrm{l}$. Experimental data revealed that adsorption isotherm fits more into the Langmuir model than that of the Freundlich model.

\section{Removal of phenol}

A comparative study by Okasha and Ibrahim (2010) investigated the phenol removal efficiency of almond shell residues, coffee grounds, black tea leaves, olive leaves and activated carbon. The results of the batch adsorption tests determined that irrespective of the adsorbent, the phenol adsorption reaches an equilibrium after $3 \mathrm{~h}$ and the percentage of phenol removed increases with a decrease in initial phenol concentration. Maximum percentage removal of phenol was found out to be $98.6 \pm 0.06,86 \pm 0.11,72 \pm 0.51$, $87 \pm 0.4,94 \pm 0.46$ and $88 \pm 0.12 \%$ for activated carbon, black tea residues, coffee ground, almond shell, date stone and olive leaves, respectively. The equilibrium data for each of the phenol-adsorbent system fit the Freundlich isotherm best particularly at concentrations below $100 \mathrm{ppm}$. On the other hand, Kazmi et al. (2013) investigated the efficiency of chemically activated tea leaves in the removal of phenol from its aqueous solution. The tea leaves were chemically modified by phosphoric acid and through UV-spectrophotometric analysis and through batch adsorption test; the adsorbent samples were found to show a maximum adsorption capacity of $63.13 \mathrm{mg} / \mathrm{g}$ under the optimal condition of $\mathrm{pH} 2,180 \mathrm{~min}$ contact time and $2 \mathrm{~g} / \mathrm{L}$ adsorbent dose. For an increase in initial phenol concentration, the adsorption capacity seemed to increase, whereas the percentage removal of phenol decreases. Experimental data revealed that the adsorption process and kinetics fit into Langmuir and pseudo-second-order models, respectively.

\section{Removal of progesterone}

Ifelebuegu and Onwugbuta (2016) investigated the efficiency of modified black tea and granulated activated carbon (GAC) at $\mathrm{pH} 7$ and $25^{\circ} \mathrm{C}$ temperature to remove progesterone from its aqueous solution. The experiment revealed black tea to have a higher maximum adsorption capacity of $1.8 \mathrm{mg} / \mathrm{g}$ than that of $1.4 \mathrm{mg} / \mathrm{g}$ capacity of GAC. The results from the batch adsorption determined that the adsorption be spontaneous and exothermic as the values of Gibb's free energy, enthalpy and entropy are calculated to be $-6.0 \mathrm{~kJ} / \mathrm{mol}$, $-3.7 \mathrm{~kJ} / \mathrm{mol}$ and $8.0 \mathrm{~J} / \mathrm{mol} \mathrm{K}$, respectively. The usage of intra-particle diffusion model to express the kinetics of progesterone adsorption showed that it was not the rate-determining step, thus indicating the adsorption was controlled by diffusion within the pores of the adsorbents.

\section{Removal of antibiotics}

Hassan and Ali (2013) investigated the potential for using spent black tea leaves for removal of tetracycline hydrochloride antibiotic from its aqueous solutions. The batch adsorption experiments evaluated the effects of variance in adsorbent dosage, contact time, $\mathrm{pH}$ of the solution and temperature on the percent removal of the $\mathrm{TCH}$ antibiotic. The results revealed that an increase in the adsorbent dosage after $0.2 \mathrm{~g}$ and contact time after $30 \mathrm{~min}$ did not increase the percent removal, whereas maximum removal occurred at a temperature and $\mathrm{pH}$ of $58{ }^{\circ} \mathrm{C}$ and 6 , respectively. The equilibrium data best fit Tempkin, and D-R equations and the kinetic studies revealed the adsorption mechanism to be of the pseudo-second-order model.

\section{Removal of benzene}

Adachi et al. (2008) investigated the use of tea leaves for the adsorption of benzene from wastewater. The spherosomes were isolated from varying amounts of tea lees using a method developed by Moreau et al. to understand the benzene removal process. The equilibrium adsorption isotherms fit the Freundlich model, and the batch adsorption tests revealed that the amount of adsorption on tea leaves was constant regardless of the $\mathrm{pH}$. The average removal efficiency was calculated to be around $72.8 \%$, which was lower 
than that of activated carbon under similar experimental conditions. It was determined that the removal of benzene by tea lees occurs due to the uptake by intracellular particles otherwise known as spherosomes.

\section{Removal of endocrine disrupting compounds (EDC)}

Ifelebuegu et al. (2015) compared the potential of untreated black tea waste and granular activated carbon in the adsorption of endocrine disrupting compounds $17 \beta$-estradiol, $17 \alpha$-ethinylestradiol and bisphenol A from their aqueous solutions. The batch adsorption experiments determined that optimal adsorption of EDCs on black tea leaves occurs at an adsorbent dosage of $1 \mathrm{~g}$ and $\mathrm{pH}$ 5. Maximum adsorption capacities of 4.01, 2.97 and $16.26 \mathrm{mg} / \mathrm{g}$ were achieved by GAC as compared to that of 3.46, 2.44 and $18.35 \mathrm{mg} / \mathrm{g}$ for tea leaves waste for $17 \beta$-estradiol, $17 \alpha$-ethinylestradiol and bisphenol A. An analysis of the kinetics and thermodynamic data revealed that the adsorption process for tea wastes was predominantly due to physisorption as opposed to chemisorption for GAC. The adsorption of the EDCs onto black tea wastes followed pseudo-first-order kinetics, whereas pseudo-second-order kinetics fit GAC. However, the experimental isotherm data for both the adsorbents fit Langmuir model more closely than Freundlich or Temkin.

Thereby it is quite evident that despite the problems related to leaching posed by the use of waste tea leaves for adsorptive purposes, they prove to be a useful alternative adsorbent under the optimal conditions. Specific studies that compared the adsorptive potential of waste tea leaves to commercially available activated carbon have successfully concluded that waste tea leaves can be used as a safe, environmentally friendly and economical alternative in its original form with little or no pre-treatment. Table 2 lists out the optimal conditions for adsorption of various metal ions and compounds as reported by the literature (Table 2).

\section{Adsorption using waste tea derived activated carbon}

The relatively high content of cellulose, hemicellulose and lignin within the cell walls of tea leaves and tea factory wastes make it a suitable precursor material for the production of activated carbon ( $\mathrm{Li}$ et al. 2010; Wang et al. 2006). There have been several studies that utilized either factoryrejected tea waste or spent tea leaves to produce AC which in turn were used as an adsorbent for the removal of organic and inorganic pollutants from wastewater.

\section{Physical activation}

Physical activation methods for the preparation of AC involved the usage of a stream of oxidizing gas for controlled gasification that was carried out post-carbonization (Shalaby et al. 2006). Fadhil et al. (2012) examined the potential of using physically activated biochar derived from spent tea waste for the purification of biodiesel. The dried spent tea leaves were simultaneously carbonized and activated either by carbonization in an electric tubular furnace at $600{ }^{\circ} \mathrm{C}$ or heating the samples under a gradual flow of steam up to $600{ }^{\circ} \mathrm{C}$ for $2 \mathrm{~h}$. Physical activation using steam showed a lower activated carbon yield of $27 \%$ as opposed to $41 \%$ of the purely thermal activation process. The use of steam in the activation process resulted in AC samples having higher surface areas but a lower methylene blue number of $39.3 \mathrm{mg} / \mathrm{g}$ as opposed to $43 \mathrm{mg} / \mathrm{g}$. Continuous adsorption tests revealed that the usage of derived activated carbon samples demonstrated greater clean biodiesel yields along with better fuel properties when compared to traditional biodiesel purification methods. The regeneration and reusability of the derived AC samples proved to be significantly more economical for biodiesel purification purposes.

Garba et al. (2015) studied the equilibrium and kinetics of the adsorption of methylene blue dye onto the surface of the activated carbon prepared from spent tea leaves. The activated carbon was prepared by carbonization at a temperature of $800{ }^{\circ} \mathrm{C}$ for $2 \mathrm{~h}$ followed by physical activation using carbon dioxide gas injected into the muffle furnace at a rate of $150 \mathrm{ml} / \mathrm{min}$ for $1.5 \mathrm{~h}$. The resultant activated carbon which had a BET surface area, micropore volume and average pore size was found to be $232.95 \mathrm{~m}^{2} / \mathrm{g}, 209.34 \mathrm{~m}^{2} / \mathrm{g}, 0.0833 \mathrm{~cm}^{3} / \mathrm{g}$ and $3.31 \mathrm{~nm}$, respectively, demonstrated an increase in the methylene blue removal when the initial concentrations, contact time and solution $\mathrm{pH}$ were increased. The absorption process followed pseudo-second-order model, and the resultant equilibrium data could be best expressed by Langmuir and Temkin isotherms that showed a maximum adsorption capacity of $114.943 \mathrm{mg} / \mathrm{g}, 119.048 \mathrm{mg} / \mathrm{g}$ and $121.951 \mathrm{mg} / \mathrm{g}$ at $303 \mathrm{~K}, 313 \mathrm{~K}$ and $323 \mathrm{~K}$, respectively.

Shen et al. (2015) used a combination of physical activation methods to prepare activated carbon from spent Jasmine tea leaves for mercury removal. The prepared precursor material was carbonized inside a muffle furnace for $2 \mathrm{~h}$ at a temperature of $500{ }^{\circ} \mathrm{C}$ before being calcined at a temperature of $700{ }^{\circ} \mathrm{C}$ for $45 \mathrm{~min}$ in a quartz bottle reactor with an activation gas mixture consisting of steam and nitrogen whose flow rates were maintained at $5 \mathrm{ml} / \mathrm{min}$ and $55 \mathrm{ml} /$ min, respectively. The activated biochar was modified with $\mathrm{NH}_{4} \mathrm{Cl}$ solutions whose concentration varied from 1 to $9 \%$. The surface characterizations revealed that the samples of the biochar that were treated with higher concentrations of $\mathrm{NH}_{4} \mathrm{Cl}$ solutions and subjected to ultrasonic treatment had higher BET surface areas as well net pore volume and average pore diameter. The study revealed that the adsorption of mercury was highest when the reaction temperature and $\mathrm{O}_{2}$ concentration were at $120^{\circ} \mathrm{C}$ and $5 \%$, respectively; whereas 
an increase in the space velocity and the presence of water had a detrimental effect on mercury adsorption.

A combination of physical and microwave activation was used by Dutta et al. (2015) for the preparation of activated carbon derived from waste tea leaves to adsorb acetaminophen from wastewater. The dried precursor material was carbonized for one hour in a muffle furnace where the heating rate was maintained at $4{ }^{\circ} \mathrm{C} / \mathrm{min}$. The char was then placed inside a domestic microwave oven for $5 \mathrm{~min}$ at an input power of $800 \mathrm{w}$ and a frequency of $2450 \mathrm{MHz}$. The prepared char was found to possess a BET surface area, total pore volume, average pore size and $\mathrm{Ph}_{\mathrm{ZPC}}$ of $493.1 \mathrm{~m}^{2} / \mathrm{g}$, $0.37 \mathrm{cc} / \mathrm{g}, 30.07 \AA$ and 7.3 , respectively. The batch adsorption tests revealed that the adsorption capacity of the derived AC was evaluated to be $195.95 \mathrm{mg} / \mathrm{g}$ and the maximum adsorption of acetaminophen occurred at an adsorbent dosage of $1 \mathrm{~g} / \mathrm{L}$ and a pH of 2 . Furthermore lowering the temperature from $40{ }^{\circ} \mathrm{C}$ to $5{ }^{\circ} \mathrm{C}$ resulted in an increase in the adsorption from 52.72 to $58.45 \mathrm{mg} / \mathrm{g}$ due to the exothermic nature of the adsorption process.

\section{Removal of carbon dioxide on waste tea derived activated carbon}

Auta et al. (2015) focused on the modification of the mesoporous activated carbon derived from waste tea leaves by impregnating it with diethanolamine to be used as a $\mathrm{CO}_{2}$ adsorbent. The $\mathrm{AC}$ was prepared using the same technique as developed by Auta and Hameed (2011a), while the modification process involved the mixing of $10 \mathrm{~g}$ of $\mathrm{AC}$ to $300 \mathrm{ml}$ of $1.0 \mathrm{M}$ diethanolamine. The modified AC packed into an adsorption column where the effects of column temperature, adsorbent loading, feed flow rate, initial diethanolamine concentration and $\mathrm{CO}_{2}$ feed concentration on the breakthrough curves were evaluated. The study found out that the adsorption process was physisorptive due to an increase in the adsorption at lower temperatures. However, maximum $\mathrm{CO} 2$ capture by modified waste tea activated carbon (MWTAC) occurred when the temperature inside the adsorption column was $30{ }^{\circ} \mathrm{C}$; feed concentration was $10 \% \mathrm{CO}_{2}$ and $1.0 \mathrm{M}$ of diethanolamine used for modification while maintaining the influent feed flow rate at $90 \mathrm{~mL} / \mathrm{min}$.

Activated carbon prepared from waste tea leaves for $\mathrm{CO}_{2}$ adsorption was investigated by Menon et al. (2015) where the effect of the activating agents, activation sequence, activating agent to waste tea leaves precursor impregnation ratio, carbonization temperature and the carbonization heating rate were evaluated. The process of chemical activation involved the usage of phosphoric acid at an impregnation ratio of $1: 1$ and $2: 1(\mathrm{~g} / \mathrm{g})$ potassium hydroxide at a ratio of $2: 1(\mathrm{~g} / \mathrm{g})$ and potassium carbonate at a ratio of $1.5: 1(\mathrm{~g} / \mathrm{g})$ before being carbonized in a muffle furnace at a temperatures ranging from $600{ }^{\circ} \mathrm{C}$ to $800{ }^{\circ} \mathrm{C}$ for $2 \mathrm{~h}$. Pre-chemical treatment involved the pyrolysis of the waste tea leaves at a temperature of $600{ }^{\circ} \mathrm{C}$ under a nitrogen atmosphere before its impregnation with phosphoric acid at an activating agent to tea leaves ratio of $1: 1$ and $2: 1(\mathrm{~g} / \mathrm{g})$, respectively. Postdrying of the mixture at $110{ }^{\circ} \mathrm{C}$ for $15 \mathrm{~h}$, the dried samples were then heated to a temperature of $800{ }^{\circ} \mathrm{C}$ inside a furnace for $2 \mathrm{~h}$. The surface and pore analysis of the samples obtained found out that the pre-chemical treated samples had the lowest surface areas of $336 \mathrm{~m}^{2} / \mathrm{g}$ and $311 \mathrm{~m}^{2} \mathrm{~g}$, respectively, whereas the chemical activation using $\mathrm{H}_{3} \mathrm{PO}_{4}$ at an impregnation ratio of $2: 1$ and carbonization at $700{ }^{\circ} \mathrm{C}$ resulted in activated carbon having the highest surface area, micropore volume and total volume of $1044 \mathrm{~m}^{2} / \mathrm{g}, 0.39$ and $0.59 \mathrm{~cm}^{3} / \mathrm{g}$, respectively. Also, the study was able to determine that carbonization at a temperature of $600{ }^{\circ} \mathrm{C}$ was ideal as the resulting $\mathrm{AC}$ would have more pores of width $1 \mathrm{~nm}$ that would be suitable for $\mathrm{CO}_{2}$ gas adsorption.

\section{Sodium hydroxide as the activating agent}

Rani et al. (2007) studied the effectiveness of the activated carbon prepared by using the same procedure as Nasuha and Hameed (2011a, b) for the adsorptive removal of basic violet-14 dye from its aqueous solution by carrying out batch adsorption studies where parameters such as $\mathrm{pH}$, temperature, adsorbent dosage and initial dye concentration were varied. The results of the experimentations revealed that the maximum adsorption occurred at $\mathrm{pH}$ of 3.5 and an increase in the temperature of the system from $30{ }^{\circ} \mathrm{C}$ to $50{ }^{\circ} \mathrm{C}$ resulted in the amount of BV-14 dye removed increasing from $40 \mathrm{mg} / \mathrm{g}$ to $41.67 \mathrm{mg} / \mathrm{g}$. Data from adsorption isotherms closely matched Freundlich isotherm than Langmuir, and the parameters suggested that the adsorption of BV-14 onto tea waste activated carbon (TWAC) followed the monolayer adsorption and pseudo-second-order kinetics. The adsorption process was spontaneous and endothermic with a positive $\Delta \mathrm{H}_{0}$ value that ranged from 20 to $26 \mathrm{~kJ} / \mathrm{mol}$ and negative $\Delta \mathrm{G}_{0}$ that ranged from -1.75 to $-5.03 \mathrm{~kJ} / \mathrm{mol}$.

Akar et al. (2013) focused on the use of activated carbon derived from spent tea leaves for the removal of malachite green from its aqueous solution and the comparison of the derived activated carbon to the non-treated waste tea leaves. The dried tea leaves were sieved to less than $210 \mu \mathrm{m}$ before being chemically activated for an hour using $4 \% \mathrm{NaOH}$ solution. The chemically activated precursor material was then carbonized for $1 \mathrm{~h}$ at a temperature of $450{ }^{\circ} \mathrm{C}$ inside a muffle furnace under a nitrogen atmosphere whose flow rate was maintained at $10 \mathrm{ml} / \mathrm{min}$. The surface characterization studies revealed that the chemical treatment resulted in the increase in surface area from 73 to $423 \mathrm{~m}^{2} / \mathrm{g}$ along with the formation of micropores. The batch equilibrium studies revealed that increasing the amount of adsorbent from 0.8 to $6 \mathrm{~g} / \mathrm{L}$ resulted in a decrease in the amount of dye 
adsorbed. Also, the elevation of $\mathrm{pH}$ from 2 to 4 resulted in the adsorption of malachite green on the activated carbon showing a decrease in the adsorption capacity marked a rapid increase from 18.7 to $123.5 \mathrm{mg} / \mathrm{g}$ while an increase in the ionic strength at $\mathrm{pH} 3$. Also, it was found out that the adsorption data better fit the Langmuir model than Freundlich or Dubinin-Radushkevich due to a higher value of correlation coefficient, while the pseudo-second-order model best explained the kinetics of the adsorption.

Islam et al. (2015) studied the effect of varying the activating agent to precursor material impregnation ratio on the surface characteristics of the activated carbon derived from factory-rejected tea and its effectiveness in the removal of methylene blue dye from aqueous solutions. The waste tea was converted into activated carbon by carbonization at a temperature of $200{ }^{\circ} \mathrm{C}$ inside a hydrothermal reactor for $5 \mathrm{~h}$ followed by chemical activation with $\mathrm{NaOH}$ solutions at impregnation ratios that varied from 1:1 to $3: 1(\mathrm{w} / \mathrm{w})$. The surface characterizations studies revealed that an increase in the amount of activation agent resulted in a significant improvement in the BET surface areas and total pore volumes from 24.45 to $368.92 \mathrm{~m}^{2} / \mathrm{g}$ and 0.02 to $0.21 \mathrm{~cm}^{3} / \mathrm{g}$, respectively. The FTIR analysis of the adsorbent was performed before and after the adsorption of methylene blue. Before the adsorption, it was found out that the treatment of the waste tea leaves with $\mathrm{NaOH}$ resulted in the hydrolysis of the esters and the protein peptide bonds into carboxylic acids and alcohols and sodium salts of the amino acids, respectively. Post-adsorption, it was observed that several functional groups had either shifted to different bands or disappeared altogether. Furthermore, it was also noted that new bands appeared correspond to $\mathrm{Si}-\mathrm{OH}, \mathrm{N}-\mathrm{H}$ stretching, $\mathrm{C}-\mathrm{H}$ aromatic benzene, asymmetric and symmetric $\mathrm{CH}_{2}$ groups in the lignin and cellulose, $\mathrm{C}-\mathrm{N}$ and $\mathrm{N}-\mathrm{O}$ (nitro). Maximum methylene blue adsorption capacity of $487.4 \mathrm{mg} / \mathrm{g}$ at $30{ }^{\circ} \mathrm{C}$ was observed on the AC that was obtained when the activating agent to precursor material ratio was set at 3:1.

\section{Sulfuric acid as the activating agent}

A study undertaken by Duran et al. (2011) examined the usage of tea industry waste based activated carbon for separation, preconcentration and speciation of chromium species. The activated carbon prepared by chemically activating the dried tea industry wastes with concentrated $\mathrm{H}_{2} \mathrm{SO}_{4}$ in $1: 1.5$ (w/v) ratio had a BET surface area, total volume, iodine and methylene blue number of $45.5 \mathrm{~m}^{2} / \mathrm{g}, 0.136 \mathrm{~cm}^{3} / \mathrm{g}$, $167.9 \mathrm{mg} / \mathrm{g}$ and $39.1 \mathrm{mg} / \mathrm{g}$, respectively. The results of batch adsorption tests on synthetic and real wastewater samples revealed that the derived activated carbon's high adsorption capacity of $61.0 \mathrm{mg} / \mathrm{g}$, high preconcentration factor of 50 per $200 \mathrm{ml}$ of sample volume and low detection limit of $0.27 \mu \mathrm{g} / \mathrm{L}$ were advantageous to the applied method that eliminated the usage of a complexing agent for the preconcentration of the chromium species. Comparison of the experimental data against different kinetic models revealed that the adsorption of chromium ions onto the derived activated carbon could be best described by the pseudo-second-order model. Furthermore, it was determined that the adsorption process is rate-limited by both intra-particle diffusion and surface adsorption.

The usage of sulfuric acid as an activating agent preparing activated carbon from spent tea leaves was investigated by Amey (2013). The waste tea leaves were digested with dilute sulfuric acid in a $0.7: 1$ activating agent to precursor material ratio for $12 \mathrm{~h}$ before being carbonized at a temperature of $500{ }^{\circ} \mathrm{C}$ inside a muffle furnace for $15 \mathrm{~min}$. The study found out that complete carbonization took place at a temperature of $450{ }^{\circ} \mathrm{C}$ and above $550{ }^{\circ} \mathrm{C}$ the material was wholly converted into ash. The XRD analysis of the precursor material and the activated carbon derived from the above process revealed a phase change from an amorphous to a crystalline form. Roy and Das (2016) prepared activated carbon from waste tea by digesting the precursor material with dilute sulfuric acid followed by carbonization at $723 \mathrm{~K}$ for defluoridation. The resultant AC has yield, bulk density, porosity and ash content of $74 \%, 0.8 \mathrm{~g} / \mathrm{cm}^{3}, 0.79$ and $12.5 \%$. The effects of adsorbent dosage, contact time and solution temperature were studied, and response surface methodology statistical technique was used to determine the optimum conditions at which defluoridation occurred by applying a two-level three-factor central composite design with the help of design expert software. It was determined that the three parameters have a significant role in determining the fluoride removal efficiency with maximum removal efficiency of $99.59 \%$ occurring at a temperature of $333 \mathrm{~K}$, contact time of $70 \mathrm{~min}$ and an adsorbent dosage of $1 \mathrm{~g}$.

The characterization of the activated carbon produced from waste tea residues was investigated by Hammud et al. (2016). Before the chemical activation using Clorox and concentrated $\mathrm{H}_{2} \mathrm{SO}_{4}$ and $\mathrm{HNO}_{3}$ mixtures, the waste tea was carbonized inside a muffle furnace for $15 \mathrm{~min}$ at a temperature of $500{ }^{\circ} \mathrm{C}$. One of the mixtures containing the $0.36 \mathrm{gm}$ of carbonized material and $5 \mathrm{ml}$ Clorox solution was mixed for an hour inside an ultrasonic apparatus, whereas the other mix consisting of $7.5 \mathrm{~g}$ of carbonized material and $70 \mathrm{ml}$ of Clorox solution was left undisturbed for $24 \mathrm{~h}$. The concentrated mixture of $\mathrm{H}_{2} \mathrm{SO}_{4}$ and $\mathrm{HNO}_{3}$ was added to the carbonized sample obtained from the muffle furnace in a 1:1 impregnation ratio and was allowed to react for over $100 \mathrm{~h}$. The SEM analysis revealed that although the usage of chemical activation agents post-carbonization in all the samples did result in the formation of microscopic porous structures on the surface, the amount of porosity was higher when the acid mixture was used as the activating agent. The results from the AFM analysis revealed that the AC obtained 
by using the acid mixture as the activating agent had the highest values of total volume $\%$ as well as average surface roughness, surface kurtosis and surface area ratio of $82.6 \%$, $0.901 \mathrm{~nm}, 1.97 \mathrm{~nm}$ and 0.248 , respectively. However, the XRD analysis (Table 3 ) pointed out that the usage of Clorox as an activating agent resulted in AC having a larger average crystallite size of $41.4 \mathrm{~nm}$ as compared to the rest of the samples.

\section{Potassium salts as the activating agents}

Work done by Auta and Hameed (2011a, b) involved the production of activated carbon from waste tea leaves and its characterization using techniques such as Brunauer-Emmett-Teller (BET and Boehm titration; as well as the comparison of the effect of solution $\mathrm{pH}$, initial concentration and temperature on the adsorption of acid blue 25 dye on the waste tea activated carbon (WTAC). The dried waste tea leaves chemically activated using potassium acetate. The resultant WTAC had a BET surface area, Langmuir surface area, average pore diameter and cumulative pore volume of $820 \mathrm{~m}^{2} / \mathrm{g}, 1224 \mathrm{~m}^{2} / \mathrm{g}, 2.458 \mathrm{~nm}$ and $0.219 \mathrm{~cm}^{3} / \mathrm{g}$, respectively, and maximum adsorption capacity of $203.34 \mathrm{mg} / \mathrm{g}$ of acid blue 25 dye at the optimum conditions. The Langmuir isotherm model represented the adsorption process quite well, and the adsorption kinetics of acid blue 25 on WTAC could be described ideally by pseudo-second-order model.

Additionally, Auta and Hameed (2011a) focused their work on the optimization of process conditions in the production of activated carbon from spent tea leaves for the adsorption of cationic and anionic dyes by using response surface methodology. The parameters studied were activation temperature, activation time and potassium acetate to waste tea leaves impregnation ratio and the percentage yield and removal were the targeted responses. The results of the statistical analysis showed that activation temperature and impregnation ratios were the factors had the most significant impact on the yield of the AC as well as the removal of methylene blue and acid blue 29 dyes. The optimal parameters for obtaining $\mathrm{AC}$ with properties that corresponded to

Table 3 Summary of optimal parameters for the production of activated carbon from waste tea

\begin{tabular}{|c|c|c|c|c|c|c|c|c|}
\hline \multirow[t]{2}{*}{ Material } & \multirow[t]{2}{*}{ Chemical } & \multirow[t]{2}{*}{ Activating agent } & \multicolumn{3}{|c|}{ Production conditions } & \multicolumn{2}{|c|}{ Evaluated parameters } & \multirow[t]{2}{*}{ References } \\
\hline & & & $\overline{\operatorname{AT}\left({ }^{\circ} \mathrm{C}\right)}$ & At (h) & IR & $\mathrm{SA}\left(\mathrm{m}^{2} / \mathrm{g}\right)$ & $\mathrm{PV}\left(\mathrm{cm}^{3} / \mathrm{g}\right)^{-}$ & \\
\hline Tea factory waste & $\mathrm{H}_{3} \mathrm{PO}_{4}$ & $\mathrm{~N}_{2}$ & 350 & 1 & $3: 1$ & 1623 & 0.667 & Yagmur et al. (2008) \\
\hline Tea factory wastes & $\mathrm{ZnCl}_{2}$ & $\mathrm{~N}_{2}$ & 700 & 1.2 & $1: 1$ & 1066 & 0.58 & Gundogdu et al. (2012) \\
\hline Tea seed shells & $\mathrm{ZnCl}_{2}$ & $\mathrm{~N}_{2}$ & 500 & 1 & $1: 1$ & - & - & Gao et al. (2013) \\
\hline $\begin{array}{l}\text { Peroxidase enzyme } \\
\text { extraction residue }\end{array}$ & $\mathrm{ZnCl}_{2}$ & $\mathrm{~N}_{2}$ & 500 & 2.5 & $1: 1$ & 613.25 & 0.285 & Abbas (2014) \\
\hline \multirow[t]{2}{*}{ Waste tea } & $\mathrm{H}_{3} \mathrm{PO}_{4}$ & $\mathrm{~N}_{2}$ & 400 & 4 & $3: 1$ & 929 & 0.547 & \multirow[t]{2}{*}{ Roy (2015) } \\
\hline & $\mathrm{NaOH}$ & $\mathrm{N}_{2}$ & 400 & 4 & $3: 1$ & 320.68 & 0.2051 & \\
\hline Jasmine tea & - & $\mathrm{N}_{2} \&$ Steam & 700 & 0.75 & - & 122.53 & 0.05497 & Shen et al. (2015) \\
\hline Matured tea leaves & $\mathrm{H}_{3} \mathrm{PO}_{4}$ & $\mathrm{~N}_{2}$ & 500 & 1 & - & 1313.41 & 1.359 & Goswami et al. (2014) \\
\hline \multirow[t]{5}{*}{ Spent tea leaves } & $\mathrm{H}_{3} \mathrm{PO}_{4}$ & - & 700 & 2 & $1: 1$ & 761 & 0.42 & \multirow[t]{5}{*}{ Menon et al. (2015) } \\
\hline & $\mathrm{H}_{3} \mathrm{PO}_{4}$ & - & 700 & 2 & $2: 1$ & 1044 & 0.59 & \\
\hline & $\mathrm{KOH}$ & - & 800 & 2 & $2: 1$ & 654 & 0.4 & \\
\hline & $\mathrm{KOH}$ & - & 600 & 2 & $2: 1$ & 711 & 0.45 & \\
\hline & $\mathrm{K}_{2} \mathrm{CO}_{3}$ & - & 600 & 2 & $1.5: 1$ & 733 & 0.36 & \\
\hline Waste tea & $\mathrm{KOH}$ & $\mathrm{N}_{2}$ & 760 & 2.25 & $1.8: 1$ & 830 & 0.524 & Auta (2012) \\
\hline Waste tea & $\mathrm{KOH}$ & $\mathrm{N}_{2}$ & 800 & 2 & $1.4: 1$ & 854.3 & 0.5162 & Auta and Hameed (2011a) \\
\hline \multirow[t]{2}{*}{ Green tea-based TFW } & $\mathrm{ZnCl}_{2}$ & $\mathrm{~N}_{2}$ & 700 & 4 & $1: 1$ & 706 & 0.369 & \multirow[t]{2}{*}{ Gundogdu et al. (2013) } \\
\hline & $\mathrm{ZnCl}_{2}$ & $\mathrm{~N}_{2}$ & 700 & 4 & $3: 1$ & 1141 & 0.806 & \\
\hline Tea dust & $\mathrm{H}_{3} \mathrm{PO}_{4}$ & - & 600 & 0.5 & $1: 1$ & 280.39 & - & Shalna and Yogamoorthi (2015) \\
\hline Tea factory waste & $\mathrm{K}_{2} \mathrm{CO}_{3}$ & $\mathrm{~N}_{2}$ & 900 & 1 & $1: 1$ & 1722 & 0.946 & Gurten et al. (2012) \\
\hline Waste tea & $\mathrm{CH}_{3} \mathrm{COOK}$ & $\mathrm{N}_{2}$ & 800 & 1.2 & $2: 1$ & 820 & 0.219 & Auta and Hameed (2011b) \\
\hline \multirow[t]{2}{*}{ Tea fruit peel } & $\mathrm{H}_{3} \mathrm{PO}_{4}$ & $\mathrm{~N}_{2}$ & 500 & 2 & $1: 1$ & 1024 & 0.7463 & \multirow[t]{2}{*}{ Gao et al. (2013) } \\
\hline & $\mathrm{ZnCl}_{2}$ & $\mathrm{~N}_{2}$ & 500 & 2 & $1: 1$ & 1320 & 0.7854 & \\
\hline TFW & $\mathrm{H}_{2} \mathrm{SO}_{4}$ & - & 200 & 2 & $1.5: 1$ & 45.5 & 0.136 & Duran et al. (2011) \\
\hline Spent black tea & $\mathrm{NaOH}$ & $\mathrm{N}_{2}$ & 450 & 1 & - & 134 & - & Akar et al. (2013) \\
\hline Waste tea & $\mathrm{H}_{3} \mathrm{PO}_{4}$ & $\mathrm{~N}_{2}$ & 800 & 2 & $2: 1$ & 232.95 & - & Garba et al. (2015) \\
\hline
\end{tabular}

$A T$ Activation temperature, $A t$ activation time, $I R$ impregnation ratio (activator: precursor), $S A$ surface area, $P V$ net pore volume 
the maximum possible yield as well as percentage removal of dyes were found out to be $800{ }^{\circ} \mathrm{C}$, IR of 1.4 and carbonization time of $120 \mathrm{~min}$. The AC produced under the optimum conditions had a BET surface area of $854.3 \mathrm{~m}^{2} / \mathrm{g}$ and had adsorption capacities of 453.12 and $554.3 \mathrm{mg} / \mathrm{g}$ for acid blue 29 and methylene blue dye, respectively. The FTIR spectra of the activated carbon derived under optimum conditions indicated the presence of saturated and unsaturated vinyl/vinylidene groups (around $3425.71 \mathrm{~cm}^{-1}$ bandwidth), derivatives of carboxylic acid group $\left(2500-1497 \mathrm{~cm}^{-1}\right), \mathrm{S}-\mathrm{O}$ inorganic sulfates and $\mathrm{Si}-\mathrm{O}-\mathrm{Si}$ asymmetric silica stretches $\left(1132.47 \mathrm{~cm}^{-1}\right)$, carboxylic acids $\mathrm{O}-\mathrm{H}$ and meta-benzene bending $\mathrm{C}-\mathrm{H}$ ( 955.34 and $759.15 \mathrm{~cm}^{-1}$, respectively). It was found out that the presence of these functional groups contributed immensely to the massive adsorption capacities of both methylene blue and acid blue 29 dyes from wastewater.

The effects of variance in conditions such as the carbonization temperature and time and the impregnation ratio and period on the characteristics of the activated carbon prepared from factory generated tea wastes were evaluated by Gurten et al. (2012). The grounded tea factory waste impregnated with $\mathrm{K}_{2} \mathrm{CO}_{3}$ in an impregnation ratio of 1:1 in all the cases before being carbonized under a nitrogen atmosphere. The change in carbonization temperature from $400{ }^{\circ} \mathrm{C}$ to $700{ }^{\circ} \mathrm{C}$ resulted in an increase in the BET surface area from $19 \mathrm{~m}^{2} / \mathrm{g}$ to $1722 \mathrm{~m}^{2} / \mathrm{g}$, a sharp increase in the micropore volumes from 0.002 to $0.570 \mathrm{~cm}^{3} / \mathrm{g}$ and a gradual decrease in the yield. A similar increase was noted upon elevating the impregnation ratio from 0.5 to 2.0 and extending the impregnation period from less than an hour to $24 \mathrm{~h}$. However, extending the carbonization time from half an hour to $2 \mathrm{~h}$ did result in a drop in the yield from 18.6 to $13.2 \%$ and the BET surface area and from 1041 to $979 \mathrm{~m}^{2} / \mathrm{g}$.

Auta (2012) prepared activated carbon from waste tea using potassium hydroxide as the activating agent for the removal of cibacron yellow dye from textile wastewaters. The following factors were taken into consideration while preparing the AC: activation temperature $\left(500{ }^{\circ} \mathrm{C}\right.$ to $\left.800^{\circ} \mathrm{C}\right)$, activation time (60-150 $\mathrm{min}$ ) and an impregnation ratio of the activating agent to waste tea (0.3 to 2.5 ). From the central composite design (CCD), two quadratic models were developed to correlate the preparation variables with the targeted responses of yield and percentage dye removal. The results indicated that yield and percentage dye removal of 21.30 and $95.07 \%$, respectively, occurred at the optimum preparation conditions of $760{ }^{\circ} \mathrm{C}$, IR 1.4 and a residence time of $120 \mathrm{~min}$. The $\mathrm{AC}$ prepared under the optimum conditions had a BET surface area and total pore volume of $830 \mathrm{~m}^{2} / \mathrm{g}$ and $0.563 \mathrm{~cm}^{3} / \mathrm{g}$, respectively. Analysis of the adsorbate distribution between the liquid and solid phase by Langmuir, Freundlich and Tempkin isotherms revealed that the cibacron yellow adsorption on the waste tea activated carbon was best described by a monolayer coverage phenomenon and the adsorbent surface was heterogeneous, i.e., it best fit the Langmuir model. The kinetics of the adsorption of the cibacron yellow dye was better described by the pseudo-second-order model due to its higher correlation coefficient values.

\section{Phosphoric acid as the activating agent}

The usage of phosphoric acid as the chemical activating agent for the preparation of activated carbon was favored in some studies as it offered several distinct advantages. Girgis and El-Hendawy (2002) reported that phosphoric acid inflicted physical and chemical modifications on the biological structure by penetration, particle swelling and partial dissolution of the biomass, bond cleavage and reformation of new polymeric structures resistant to thermal decomposition.

The influence of microwave treatment alongside chemical activation on waste tea precursor material was examined by Yagmur et al. (2008) where the characterization studies compared the effect of pre-treatment methods, carbonization temperatures and impregnation ratios on activated carbons. The tea factory wastes were chemically activated with $85 \%$ $\mathrm{H}_{3} \mathrm{PO}_{4}$ solution at the various activating agent to precursor material impregnation ratios that ranged from 1:1 to 3:1. Microwave treatment of the impregnated samples occurred at an input power of $900 \mathrm{~W}$ and a frequency of $2.45 \mathrm{GHz}$ for the $30 \mathrm{~s}$. The changes caused by microwave treatment on the surface morphology and chemical structure of the waste tea were revealed by the characterization studies that showed that the microwave pre-treatment method resulted in shorter chemical activation times and consistent improvements in the micropore surface area and pore volume of the AC samples as compared to that obtained by conventional treatment. The Dubinin-Radushkevich (DR) method of analysis revealed that increasing the impregnation ratio from $1: 1$ to $3: 1$ resulted in the micropore surface areas increasing from $1459 \mathrm{~m}^{2} / \mathrm{g}$ to $1630 \mathrm{~m}^{2} / \mathrm{g}$, but an increase in the carbonization temperature while keeping the impregnation ratio constant at $3: 1$ from $300{ }^{\circ} \mathrm{C}$ to $700{ }^{\circ} \mathrm{C}$ was marked by a rapid increase in the surface area until $350{ }^{\circ} \mathrm{C}$ followed by a gradual decline.

The potential for using tea plantation wastes as a low-cost precursor material for preparing activated carbon to adsorb p-nitrophenol from wastewater was investigated by Ahmaruzzaman and Gayatri (2010). The preparation of the AC evaluated the potential of $\mathrm{NaOH}, \mathrm{KOH}, \mathrm{ZnCl}_{2}, \mathrm{MnO}_{2}, \mathrm{H}_{3} \mathrm{PO}_{4}$ and $\mathrm{H}_{2} \mathrm{O}_{2}$ as activating agents before the carbonization of the mixture at a temperature of $500{ }^{\circ} \mathrm{C}$. It was determined that the usage of $\mathrm{H}_{3} \mathrm{PO}_{4}$ results in $\mathrm{AC}$ samples demonstrating a greater p-nitrophenol adsorption capacity. The resultant AC had a BET surface area, pore size and fixed carbon content of $29.5 \mathrm{~m}^{2} / \mathrm{g}, 2.1 \mathrm{~nm}$ and $57.1 \%$. The data obtained from the batch adsorption experiments fit the Langmuir model 
more closely thereby indicating monolayer adsorption of p-nitrophenol molecules on the surface of the adsorbent with a maximum adsorption capacity of $142.85 \mathrm{mg} / \mathrm{g}$.

The characterization and the ability of the activated carbon prepared from waste tea leaves as the precursor material for the adsorption of $\mathrm{Ni}$ (II) ions were investigated by Goswami et al. (2014). The tea waste was converted into activated carbon by chemical activation using $2 \mathrm{M}$ phosphoric acid or sodium hydroxide at an activating agent to precursor material impregnation ratio of $3: 1$ followed by carbonization at a temperature of $400{ }^{\circ} \mathrm{C}$ for $4 \mathrm{~h}$. The characterization studies revealed that the $\mathrm{AC}$ obtained by using $\mathrm{H}_{3} \mathrm{PO}_{4}$ as the activating agent had a BET surface area and total pore volume of $929 \mathrm{~m}^{2} / \mathrm{g}$ and $0.547 \mathrm{~cm}^{3} / \mathrm{g}$, respectively. This was significantly higher in comparison with the AC obtained by using $\mathrm{NaOH}$ as the activating agent as it had a surface area of $320.68 \mathrm{~m}^{2} / \mathrm{g}$ and net pore volume of $0.2051 \mathrm{~cm}^{3} / \mathrm{g}$. The batch adsorption tests revealed that the former exhibited a maximum adsorption capacity of $98 \mathrm{mg} / \mathrm{g}$ of $\mathrm{Ni}(\mathrm{II})$ ions at $\mathrm{pH}$ 5. Comparison of the experimental data against Langmuir, Tempkin and Freundlich isotherms indicated that the Langmuir isotherm is the best-fitted model for $\mathrm{Cr}(\mathrm{IV})$ adsorption on activated carbon. The kinetics of the adsorption could be well described by the pseudo-secondorder model, while linearity of the $\mathrm{q}^{\mathrm{t}}$ versus $\mathrm{t}^{0.5}$ indicated that intra-particle diffusion played a significant role in the adsorption of $\mathrm{Cr}(\mathrm{IV})$ ions.

Goswami et al. (2014) investigated the equilibrium modeling as well as kinetic and thermodynamics of the adsorption of $\mathrm{Cr}(\mathrm{IV})$ on the activated carbon derived from waste tea leaves. The AC was prepared by adding $85 \%$ orthophosphoric acid to the waste tea precursor before carbonization at a temperature of $500^{\circ} \mathrm{C}$ for $1 \mathrm{~h}$. The resultant material had a BET surface area and total pore volume of $1313.41 \mathrm{~m}^{2} / \mathrm{g}$ and $1.359 \mathrm{~cm}^{3} / \mathrm{g}$, respectively. The batch adsorption experiments revealed that the adsorption capacity remained optimum between $\mathrm{pH} 1.5$ and 4.8, whereas an increase in the temperature improved the adsorption capacity from 25.36 to $32.04 \mathrm{mg} / \mathrm{g}$ when the initial $\mathrm{Cr}(\mathrm{IV})$ concentration was maintained at $60 \mathrm{mg} / \mathrm{L}$. The experimental data obtained best fit the Langmuir isotherm, and the adsorption process itself followed the pseudo-second-order kinetic model. The values $\Delta \mathrm{G}_{0}, \Delta \mathrm{H}_{0}$ and $\Delta \mathrm{S}$ at $313 \mathrm{k}$ were calculated to be $-1.09 \mathrm{~kg} /$ $\mathrm{mol}, 28.6 \mathrm{~kg} / \mathrm{mol}$ and $94.87 \mathrm{~J} / \mathrm{mol} \mathrm{K}$, respectively, indicating a spontaneous and endothermic nature of the adsorption process.

Shalna and Yogamoorthi (2015) examined the differences in the characterizations of commercially available activated carbon derived from Jatropha husk and activated carbon prepared from spent tea dust. The tea dust was chemically activated with orthophosphoric acid for $24 \mathrm{~h}$ before being carbonized at a temperature of $600{ }^{\circ} \mathrm{C}$ for half an hour. The characterizations studies revealed that the $\mathrm{AC}$ prepared from tea dust had a significantly lower moisture content (1.9\%) but a higher ash content. The commercially available AC had a greater surface area and carbon content of $890 \mathrm{~m}^{2} / \mathrm{g}$ and $89.98 \%$, respectively, as compared to $280 \mathrm{~m}^{2} / \mathrm{g}$ and $73.09 \%$ of the tea dust-based AC.

\section{Zinc chloride as the activating agent}

Zinc chloride is widely used for the chemical activation of carbonaceous material as it results in ACs being more porous and having a high surface area while acting as a dehydrating agent that promotes the decomposition of carbonaceous material, restricts tar formation and increases the carbon yield (Ahmadpour and Do 1997; Khalili et al. 2000). Gao et al. (2013) studied and compared the properties of the AC produced from tea fruit peel residue using zinc chloride and phosphoric acid as the activation agents. The impregnation ratio was maintained at 1:1 (w/w) in both the cases, and the carbonization was done in a muffle furnace at a temperature of $500{ }^{\circ} \mathrm{C}$ for 20 min under an $\mathrm{N}_{2}$ atmosphere. The characterization studies revealed that the use of zinc chloride as the activating agent resulted in the AC samples having greater BET surface area, micropore volume and $\mathrm{pH}$ zero point charge but lower average pore diameter, mesopore volume and overall yield. The results from the batch adsorption tests revealed that zinc chloride-based AC had a higher methylene blue adsorption capacity of $342.5 \mathrm{mg} / \mathrm{g}$ as opposed to $291.5 \mathrm{mg} / \mathrm{g}$ of the phosphoric acid-based AC.

Gundogdu et al. (2013) study focused on understanding the changes in the physiochemical characteristics of the activated carbon that was produced from tea industry wastes by varying the activating agent to tea waste precursor impregnation ratios. Zinc chloride was added at impregnation ratios of $0.5: 1,1: 1$ and $2: 1(\mathrm{~g} / \mathrm{g})$ separately to the waste tea. The samples were carbonized inside a high-temperature furnace for $4 \mathrm{~h}$ at a temperature of $700{ }^{\circ} \mathrm{C}$ under an atmosphere of nitrogen whose flow rate was maintained at $100 \mathrm{ml} / \mathrm{min}$. An extensive characterization study including quantitative measurement of various parameters by proximate analysis revealed that increasing the amount of zinc chloride as the activating agent results in a comparatively higher yield of $\mathrm{AC}$ as compared to the usage of $\mathrm{KOH}$. Increasing the activating agent to the tea waste impregnation ratio resulted in more structural fractures that contributed to the lower carbonization yield. Comparison of the SEM micrographs of the three samples of AC revealed that the increase in the amount of activating agent resulted in higher levels of mesoporosity in the surface. BET analysis of the three samples confirmed that the increase in the amount of activating agent resulted in an increase in the surface area of the material along with an enhanced porous structure. The AC obtained by using the addition of $\mathrm{ZnCl}_{2}$ in a 3:1 impregnation ratio had a BET 
surface area, total pore volume and average pore diameters of $1141 \mathrm{~m}^{2} / \mathrm{g}, 0.806 \mathrm{~cm}^{3} / \mathrm{g}$ and $2.83 \mathrm{~nm}$, respectively.

Gundogdu et al. (2012)also studied the kinetic, equilibrium and thermodynamic parameters to evaluate the ability of activated carbon derived from waste tea leaves to adsorb phenol molecules from an aqueous solution. The activated carbon was produced by chemical activation with zinc chloride in a precursor to activating agent ratio of $1: 1$ followed by carbonization inside a high-temperature furnace for $4 \mathrm{~h}$ at a temperature of $700{ }^{\circ} \mathrm{C}$. The characterization study revealed that the resultant activated carbon had a significantly high carbon content of $79.32 \%$ along with a BET surface area, total pore volume, iodine number and methylene blue number of $1066 \mathrm{~m}^{2} / \mathrm{g}, 0.580 \mathrm{~cm}^{3} / \mathrm{g}, 605.8 \mathrm{mg} / \mathrm{g}$ and $100.2 \mathrm{mg} / \mathrm{g}$, respectively. The batch adsorption tests revealed that the adsorption of phenol molecules on the activated carbon could be better understood by Langmuir adsorption and pseudo-second-order kinetic model and both boundary layer diffusion as well as intra-particle diffusion controlled the adsorption rate. The linear Langmuir equation revealed that the maximum adsorption capacity was $142.9 \mathrm{mg} / \mathrm{g}$ and this adsorption capacity was adversely affected by an increase in temperature due to the exothermic nature of the adsorption process. Furthermore, the increase in the ionic strength of the aqueous solution had a corresponding increase in the adsorption of phenol molecules on the AC.

Tea seed shell base activated carbon was prepared by Gao et al. (2013). Zinc chloride was added to the precursor material at an impregnation ratio of $1: 1$ before being carbonized in a muffle furnace at a temperature of $500{ }^{\circ} \mathrm{C}$ for $1 \mathrm{~h}$. The $\mathrm{N}_{2}$ adsorption and desorption isotherms at $77 \mathrm{~K}$ revealed it to be a type 1 isotherm as per IUPAC standards, which indicated the presence of a large percentage of micropores along with smaller fractions of mesopores. The BET surface area and the total pore volume of the AC were $1530.67 \mathrm{~m}^{2} / \mathrm{g}$ and $0.7826 \mathrm{~cm}^{3} / \mathrm{g}$, respectively. The FTIR analysis of the activated carbon samples revealed that the existence of the various functional groups including hydroxyl, phenol and other oxygen-containing compounds. The study came to the conclusion that the functional groups present on the surface of the activated carbon were connected to the adsorption mechanism by hydrogen bonding and $\pi-\pi$ dispersion interaction between the electrons of the adsorbent and the adsorbate. The data obtained from the equilibrium adsorption tests closely collaborated to the Langmuir isotherm model, and the maximum monolayer adsorption capacity of methylene blue was $324.7 \mathrm{mg} / \mathrm{g}$. Kinetic and thermodynamic analysis revealed that the rate of adsorption was not controlled just by intra-particle diffusion and the sorption process itself was spontaneous and exothermic.

Abbas (2014) prepared activated carbon from waste tea leaves that were previously used for the adsorption of zinc ions by chemically activating them using zinc chloride solution of concentration $11 \mathrm{~g} / \mathrm{L}$ before being carbonized at a temperature of $500{ }^{\circ} \mathrm{C}$ under an $\mathrm{N}_{2}$ atmosphere. The characterization studies on the resultant $\mathrm{AC}$ revealed it to have a BET surface area, total pore volume and pore diameter of $613.35 \mathrm{~m}^{2} / \mathrm{g}, 0.285 \mathrm{~cm}^{3} / \mathrm{g}$ and $1.75 \mathrm{~nm}$, respectively. Batch adsorption experiments determined that under optimal conditions of $\mathrm{pH} 1$ and an agitation speed of $400 \mathrm{rpm}$, $0.1 \mathrm{~g}$ of activated carbon had a thiophenol removal efficiency of $97.99 \%$. The experimental data about the adsorption of thiophenol best fit the Langmuir adsorption isotherm, while the kinetics of the adsorption could be explained more accurately by the pseudo-second-order model.

The characteristics of the activated carbon produced by using waste tea leaves or related organic material as the precursor depend significantly on the activating conditions, activation temperature, activation time and the activating agent and the chemical used. Furthermore, the activated carbon produced from tea leaves can be tailored made for specific adsorptive applications. The data presented provide ease of comparison between the characteristics and the production conditions as reviewed in the literature (Table 3 ).

\section{Conclusions}

The widespread ability and the ease with which waste tea leaves can be obtained combined with attractive physiochemical characteristics make it a potential replacement for commercially used adsorbents. In addition to the cost-benefits, the usage of tea leaves as a bio-adsorbent eliminates the multitude of environmental issues generated by its disposal. Adequate pre-treatment methods such as the usage of formaldehyde can reduce the problems associated with leaching when tea leaves are used for sorption purposes. Furthermore, it is an ideal low-cost precursor material for the production of activated carbon using conventional physical activation or impregnation methods due to its widespread availability when compared to the commonly used adsorbents. The properties of the activated carbons produced from waste tea leaves depend heavily on the activation method, type of activating agent and the process conditions such as temperature, retention time and impregnation ratios. Chemical activation methods seem to produce activated carbons possessing better properties as compared to physical activation methods. Results from the studies show that under ideal conditions, waste tea derived activated carbons can have features that are at par with the commercially available one. Waste tea-based AC's demonstrates a high level of efficiency in the removal of several classes of pollutants at the optimum parameters.

- Waste tea leaves when chemically activated have potential to be used as low-cost adsorbents for various metal ions and other wastewater effluents. The problems related

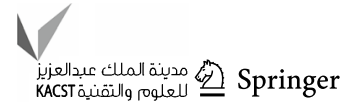


to leaching commonly associated with tea-based adsorbents can be overcome by treating it with mild solutions of formaldehyde.

- It is preferable to convert the waste tea leaves into activated carbon before being used for adsorptive purposes as the latter boasts significantly higher effluent adsorptive capacities which in turn reduces the amount of adsorbent needed.

- Under right impregnation ratios, activation temperature and time, the activated carbon produced from waste tea precursor possess properties similar to some grades of commercially available granular activated carbon. However, when the use of potassium acetate as the chemical activating agent is combined with a prolonged activation time, the resultant $\mathrm{AC}$ possesses remarkably high values of BET surface area and net pore volume.

- One of the limitations of the study was that the influence of using microwave energy-assisted activation for the synthesis of activated carbon from waste tea leaves was not critically evaluated. Although this was attributed to the limited number of associated literature, it does represent untapped potential for expanding this work.

- However, detailed studies are required to comprehend the efficiency of using waste tea for adsorption purposes in real life and the economics of using it as an alternative precursor material for the industrial production of activated carbon.

Open Access This article is distributed under the terms of the Creative Commons Attribution 4.0 International License (http://creativeco mmons.org/licenses/by/4.0/), which permits unrestricted use, distribution, and reproduction in any medium, provided you give appropriate credit to the original author(s) and the source, provide a link to the Creative Commons license, and indicate if changes were made.

\section{References}

Abbas MN (2014) Application of used tea leaves for multi functions. Eur Acad Res 2(7):8660-8690

Adachi A, Ioku A, Taniyama K, Okano T (2008) Use of tea or coffee lees as adsorbent for removal of benzene from wastewater. J Health Sci 54(4):478-481

Ahluwalia SS, Goyal D (2005) Removal of heavy metals by waste tea leaves from aqueous solution. Eng Life Sci 5(2):158-162. https ://doi.org/10.1002/elsc.200420066

Ahmad AA, Hameed BH (2009) Reduction of COD and color of dyeing effluent from a cotton textile mill by adsorption onto bamboobased activated carbon. J Hazard Mater 172(2-3):1538-1543. https://doi.org/10.1016/j.jhazmat.2009.08.025

Ahmadpour A, Do DD (1997) The preparation of activated carbon from macadamia nutshell by chemical activation. Carbon 35(12):17231732. https://doi.org/10.1016/S0008-6223(97)00127-9

Ahmaruzzaman M, Gayatri SL (2010) Activated tea waste as a potential low-cost adsorbent for the removal of $\mathrm{p}$-nitrophenol from wastewater. J Chem Eng Data 55(11):4614-4623. https://doi. org/10.1021/je100117s

Ajmal M, Rao RAK, Khan MA (2005) Adsorption of copper from aqueous solution on Brassica cumpestris (mustard oil cake). J Hazard Mater 122(1-2):177-183. https://doi.org/10.1016/j.jhazm at.2005.03.029

Akar E, Altinişik A, Seki Y (2013) Using activated carbon produced from spent tea leaves for the removal of malachite green from aqueous solution. Ecol Eng. https://doi.org/10.1016/j.ecole ng.2012.12.032

Amey WA (2013) Preparation of low cost activated carbon from tea waste using sulphuric acid as activating agent. ISSN Int Res J Environ Sci 2(4):2319-2414

Auta M (2012) Optimization of tea waste activated carbon preparation parameters for removal of cibacron yellow dye from textile waste waters. Int J Adv Eng Res 1(4):50-56

Auta M, Hameed BH (2011a) Optimized waste tea activated carbon for adsorption of Methylene Blue and Acid Blue 29 dyes using response surface methodology. Chem Eng J. https://doi. org/10.1016/j.cej.2011.09.100

Auta M, Hameed BH (2011b) Preparation of waste tea activated carbon using potassium acetate as an activating agent for adsorption of Acid Blue 25 dye. Chem Eng J. https://doi.org/10.1016/j. cej.2011.04.017

Auta M, Umaru M, Yahya M, Adeniyi O, Aris IM, Suleiman B (2015) Diethanolamine functionalized waste tea activated carbon for $\mathrm{CO} 2$ adsorption (C). In: International conference on chemical, environmental and biological science. Dubai

Baccar R, Bouzid J, Feki M, Montiel A (2009) Preparation of activated carbon from Tunisian olive-waste cakes and its application for adsorption of heavy metal ions. J Hazard Mater 162:1522-1529

Bhargava SK, Tardio J, Prasad J, Föger K, Akolekar DB, Grocott SC (2006) Wet oxidation and catalytic wet oxidation. Ind Eng Chem Res 45(4):1221-1258. https://doi.org/10.1021/ie051059n

Cay S, Uyanlik A, Özalcslik A (2004) Single and binary component adsorption of copper (II) and cadmium (II) from aqueous solutions using tea-industry waste. Sep Purif Technol 38(3):273-280

Chandra TC, Mirna MM, Sunarso J, Sudaryanto Y, Ismadji S (2009) Activated carbon from durian shell: preparation and characterization. J Taiwan Inst Chem Eng 40(4):457-462. https://doi. org/10.1016/j.jtice.2008.10.002

Chatterjee A, Saluja M, Agarwal G, Alam M (2012) Green tea: a boon for periodontal and general health. J Indian Soc Periodontal 16:161-167

Cheraghi M, Sobhanardakani S, Zandipak R, Lorestani B, Merrikhpour $\mathrm{H}$ (2015) Removal of $\mathrm{Pb}$ (II) from aqueous solutions using waste tea leaves. Iran J Toxicol 9(28):1247-1253

Demiral H, Gündüzog G (2010) Bioresource technology removal of nitrate from aqueous solutions by activated carbon prepared from sugar beet bagasse. Biores Technol 101(101):1675-1680. https:// doi.org/10.1016/j.biortech.2009.09.087

Deng H, Yang L, Tao G, Dai J (2009) Preparation and characterization of activated carbon from cotton stalk by microwave assisted chemical activation-Application in methylene blue adsorption from aqueous solution. J Hazard Mater 166(2-3):1514-1521. https://doi.org/10.1016/j.jhazmat.2008.12.080

Duran C, Ozdes D, Gundogdu A, Imamoglu M, Senturk HB (2011) Tea-industry waste activated carbon, as a novel adsorbent, for separation, preconcentration and speciation of chromium. Anal Chim Acta. https://doi.org/10.1016/j.aca.2010.12.029

Dutta M, Das U, Mondal S, Bhattachriya S, Khatun R, Bagal R (2015) Adsorption of acetaminophen by using tea waste derived activated carbon. Int J Environ Sci. https://doi.org/10.6088/ijes.6031

Fadhil AB, Dheyab MM, Abdul-Qader AQY (2012) Purification of biodiesel using activated carbons produced from spent tea waste. 
J Assoc Arab Univ Basic Appl Sci. https://doi.org/10.1016/j.jauba s.2011.12.001

Fauziah S, Draman S, Mohd N, Hafiza N, Wahab I, Zulkfli NS, Fatin $\mathrm{N}$ (2015) Adsorption of lead (Ii) ions in aqueous solution using selected agro-waste. ARPN J Eng Appl Sci 10(1):297-300

Gao J, Kong D, Wang Y, Wu J, Sun S, Xu P (2013) Production of mesoporous activated carbon from tea fruit peel residues and its evaluation of methylene blue removal from aqueous solutions. BioResources 8:2145-2160

Garba ZN, Faezah S, Soib B, Rahim AA (2015) Valuation of activated carbon from waste tea for the removal of a basic dye from aqueous solution. J Chem Eng Chem Res 2(5):623-633

Girgis BS, El-Hendawy ANA (2002) Porosity development in activated carbons obtained from date pits under chemical activation with phosphoric acid. Microporous Mesoporous Mater 52(2):105-117. https://doi.org/10.1016/S1387-1811(01)00481 $-4$

Goswami M, Borah L, Mahanta D, Phukan P (2014) Equilibrium modeling, kinetic and thermodynamic studies on the adsorption of $\mathrm{Cr}(\mathrm{VI})$ using activated carbon derived from matured tea leaves. J Porous Mater. https://doi.org/10.1007/s10934-014-9852-1

Gundogdu A, Duran C, Senturk HB, Soylak M, Ozdes D, Serencam H, Imamoglu M (2012) Adsorption of phenol from aqueous solution on a low-cost activated carbon produced from tea industry waste: equilibrium, kinetic, and thermodynamic study. J Chem Eng Data. https://doi.org/10.1021/je300597u

Gundogdu A, Duran C, Senturk HB, Soylak M, Imamoglu M, Onal Y (2013) Physicochemical characteristics of a novel activated carbon produced from tea industry waste. J Anal Appl Pyrol. https://doi. org/10.1016/j.jaap.2013.07.008

Gurten II, Ozmak M, Yagmur E, Aktas Z (2012) Preparation and characterisation of activated carbon from waste tea using $\mathrm{K}_{2} \mathrm{CO}_{3}$. Biomass Bioenerg. https://doi.org/10.1016/j.biombioe.2011.12.030

Hammud KK, Raouf AM, Mohammed A, Al-Sammarrie A, Neema RR (2016) New chemically prepared-waste cooked tea based activated carbon: FTIR, XRD, AFM, and SEM spectroscopic studies. Int J Res Pharm Chem 6(2):220-229

Harbowy ME, Balentine AD, Davies AP (1997) Tea chemistry. Crit Rev Plant Sci 16(5):415-480. https://doi.org/10.1080/713608154

Harler C (1963) Tea manufacture. Oxford University Press, London

Hassan S, Ali F (2013) Usability study of spent black tea leaves and pomegranate peel in adsorption. Int J Curr Res 5(9):2530-2538

Ifelebuegu AO, Onwugbuta NE (2016) An evaluation of the removal of progesterone in wastewater by adsorption onto waste tea leaves. In: Fourth International conference on advances in applied science and environmental technology. https://doi.org/10.15224/978-163248-097-2-43

Ifelebuegu AO, Ukpebor JE, Obidiegwu CC, Kwofi BC (2015) Comparative potential of black tea leaves waste to granular activated carbon in adsorption of endocrine disrupting compounds from aqueous solution. Glob J Environ Sci Manag 1(3):205-214. https ://doi.org/10.7508/GJESM.2015.03.003

Islam MA, Benhouria A, Asif M, Hameed BH (2015) Methylene blue adsorption on factory-rejected tea activated carbon prepared by conjunction of hydrothermal carbonization and sodium hydroxide activation processes. J Taiwan Inst Chem Eng. https://doi. org/10.1016/j.jtice.2015.02.010

Jeyaseelan C, Gupta A (2016) Green tea leaves as a natural adsorbent for the removal of $\mathrm{Cr}(\mathrm{VI})$ from aqueous solutions. Air, Soil Water Res. https://doi.org/10.4137/ASWr.S35227

Jung S, Naidoo M, Shairzai S, Navarro AE (2014) On the adsorption of a cationic artificial dye on spent tea leaves. WIT Trans Built Environ 139:231-241. https://doi.org/10.2495/UW140201

Kazmi M, Saleemi AR, Feroze N, Yaqoob A, Ahmad SW (2013) Removal of phenol from wastewater using activated waste tea leaves. Polish J Chem Technol 15(2):1-6
Khalili NR, Campbell M, Sandi G, Golas J (2000) Production of microand mesoporous activated carbon from paper mill sludge I. Effect of zinc chloride activation. Pergamon Carbon 38(38):1905-1915

Khan N, Yahaya EM, Faizal M, Mohamed P, Abustan I, Azmier M (2010) Effect of preparation conditions of activated carbon prepared from rice husk by $\mathrm{ZnCl}_{2}$ activation for removal of $\mathrm{Cu}$ (II) from aqueous solution. J Eng Technol 6:1-5

Khosla E, Kaur S, Dave PN (2011) Surfactant modified tea waste as a novel adsorbent for the removal of Basic dye. Pelagia Res Library Der Chem Sin 2(5):87-102

Kondo M, Sato H (1994) Treatment of wastewater from phenolic resin process by pervaporation. Desalination $98(1-3): 147-154$. https:// doi.org/10.1016/0011-9164(94)00139-1

Kula I, Uğurlu M, Karaoğlu H, Celik A (2008) Adsorption of Cd (II) ions from aqueous solutions using activated carbon prepared from olive stone by $\mathrm{ZnCl}_{2}$ activation. Biores Technol 99(3):492-501

Kumar H, Sumint T, Trivedia S, Pandey LK (2015) Tea waste adsorbent for the removal of chromium and copper from synthetic wastewater. IJIRST Int J Innov Res Sci Technol 2(2):70-74

Li Q, Chai L, Yang Z, Wang Q, Wang Y (2010) A comparative study of $\mathrm{Ag}(\mathrm{I})$ adsorption on raw and modified spent grain: kinetic and thermodynamic aspects. WaterEnvironRes 82:2290-2296

Macfarlane A, Macfarlane I (2011) Green gold: the empire of tea. The OverLook Press. https://books .google.co.in/books ?hl=en \&1r=\&id=4SCZJ FFf6Z $\mathrm{sC} \& \mathrm{o} i=\mathrm{fnd} \& \mathrm{pg}=\mathrm{PT} 4 \& \mathrm{dq}=+$ te $\mathrm{a}+\mathrm{mania}++\mathrm{Assam}$ + Tea\&ots $=$ EDzCP_nPh0\&sig=gomQum3z1ckVQppXiudz Qhk1GpY

Mahvi AH (2009) Application of agricultural fibers in pollution removal from aqueous solution. Int J Environ Sci Technol 5(2):275-285. https://doi.org/10.1007/BF03326022

Malakahmad A, Tan S, Yavari S (2016) Valorization of wasted black tea as a low-cost adsorbent for nickel and zinc removal from aqueous solution. J Chem. https://doi.org/10.1155/2016/5680983

Malkoç E, Nuhoglu Y (2003) The removal of Chromium (VI) from synthetic Wastewater by Ulothrix zonata. Fresenius Environ Bull 12(4):376-381

Matta GK, Barros MAS, Lambrecth R, Da Silva E, da Motta Lima O (2008) Dynamic isotherms of dye in activated carbon. Mater Res 2(3):365-369

Menon R, Singh J, Doshi V, Lim XY (2015) Investigation on spent tea leaves derived activated carbon for co 2 adsorption. J Eng Sci Technol EURECA 2014 Special Issue April, pp 50-61

Nasuha N, Hameed BH (2011a) Adsorption of methylene blue from aqueous solution onto $\mathrm{NaOH}$-modified rejected tea. Chem Eng J 166(2):783-786. https://doi.org/10.1016/j.cej.2010.11.012

Nasuha N, Hameed BH (2011b) Adsorption of methylene blue from aqueous solution onto $\mathrm{NaOH}$-modified rejected tea. Chem Eng J. https://doi.org/10.1016/j.cej.2010.11.012

Nuhoglu Y, Malkoc E, Gürses A, Canpolat N (2002) The removal of $\mathrm{Cu}$ (II) from aqueous solutions by Ulothrix zonata. Biores Technol 85(3):331-333. https://doi.org/10.1016/S0960-8524(02)00098-6

Okasha AY, Ibrahim HG (2010) Phenol removal from aqueous systems by sorption of using some local waste materials. Electron J Environ Agric Food Chem 9:796-807

Oliveira L, Pereira E, Guimaraes I, Vallone A, Pereira M, Mesquita J, Sapag K (2009) Preparation of activated carbons from coffee husks utilizing $\mathrm{FeCl} 3$ and $\mathrm{ZnCl} 2$ as activating agents. J Hazard Mater 165:87-94

Orhan Y, Büyükgüngör H (1993) The removal of heavy metals by using agricultural wastes. Water Sci Technol 28(2):247-255

Pajooheshfar SP, Saeedi M (2009) Adsorptive removal of phenol from contaminated water and wastewater by activated carbon, almond, and walnut shells charcoal. Water Environ Res 81(6):641-648. https://doi.org/10.2175/106143008x390780

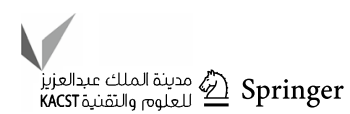


Peng C, Yan X Bin, Wang RT, Lang JW, Ou YJ, Xue QJ (2013) Promising activated carbons derived from waste tea-leaves and their application in high performance supercapacitors electrodes. Electrochim Acta 87(87):401-408. https://doi.org/10.1016/j.elect acta.2012.09.082

Plaza MG, Pevida C, Martín CF, Fermoso J, Pis JJ, Rubiera F (2010) Developing almond shell-derived activated carbons as $\mathrm{CO} 2$ adsorbents. Sep Purif Technol 71(1):102-106. https://doi.org/10.1016/j. seppur.2009.11.008

Rani KM, Palanisamy PN, Gayathri S, Tamilselvi S, Professor A (2007) Adsorptive removal of basic violet dye from aqueous solution by activated carbon prepared from tea dust material. Int J Innov Res Sci Eng Technol. https://doi.org/10.15680/IJIRSET.2015.0408020

Reza A, Sheikh FA, Kim H, Zargar MA, Zainal Abedin M (2016) Facile and efficient strategy for removal of reactive industrial dye by using tea waste. Adv Mater Lett Adv Mater Lett 7(711):878-885. https://doi.org/10.5185/amlett.2016.6363

Rossner A, Snyder S (2009) Removal of emerging contaminants of concern by alternative adsorbent. Water Res 43(15):3787-3796

Roy S (2015) Batch adsorption of Ni(II) on low cost activated carbon prepared from tea waste precursor. Int J Eng Sci Res-IJESR, 3(1). http://technicaljournals.org

Roy S, Das P (2016) Assessment on the defluoridation using novel activated carbon synthesized from tea waste: batch, statistical optimization and mathematical modeling. J Ind Pollut Control 32(2):544-553

Shah J, Jan MR, Ul Haq A, Zeeshan M (2015) Equilibrium, kinetic and thermodynamic studies for sorption of $\mathrm{Ni}$ (II) from aqueous solution using formaldehyde treated waste tea leaves. J Saudi Chem Soc. https://doi.org/10.1016/j.jscs.2012.04.004

Shalaby CS, Astharlioglu MGU, Artok L, Sarici C (2006) Preparation and characterization of activated carbons by one-step steam pyrolysis/activation from apricot stones ${ }^{`}$ dem S. Microporous Mesoporous Mater 88(88):126-134. https://doi.org/10.1016/j. micromeso.2005.09.003

Shalna T, Yogamoorthi A (2015) Preparation and characterization of activated carbon from used tea dust in comparison with commercial activated carbon. Int J Recent Sci Res 6(2):2750-2755

Shen B, Li G, Wang F, Wang Y, He C, Zhang M, Singh S (2015) Elemental mercury removal by the modified bio-char from medicinal residues. Chem Eng J. https://doi.org/10.1016/j.cej.2015.03.006

Srinivasan K, Balasubramanian N, Ramakrishna TV (1988) Studies on chromium removal by rice husk carbon. Indian J Environ Health 30(4):376-387

Srivastava SK, Tyagi R, Pal N, Mohan D (1997) Process development for removal of substituted phenol by carbonaceous adsorbent obtained from fertilizer waste. J Environ Eng-ASCE 123(9):842851. https://doi.org/10.1061/(asce)0733-9372(1997)123:9(842)

Tan WT (1985) Copper(II) adsorption by waste tea leaves and coffee powder. Pertanika 8(2):223-230

Thakur LS, Parmar M (2013) Synthetic waste water by tea waste adsorbent. Int J Chem Phys Sci 2(6):6-19

Thapak HK, Sharma J, Boudh B, Banger N, Dwivedia P (2015) Adsorption of copper ions in aqueous media using tea waste and sawdust as an adsorbent. IJIRST Int J Innov Res Sci Technol 2(3):52-57

Troup R, Hayes J, Raatz S, Thyagarajan B, Khaliq W, Jacobs D, Key N, Morawski B, Kaiser D, Bank A (2015) Effects of black tea on blood cholesterol concentrations in individuals with mild hypercholesterolemia: a diet controlled randomized trial. J Acad Nutr Diet 115(2):264-271

Ubago-Pérez R, Carrasco-Marín F, Fairén-Jiménez D, Moreno-Castilla C (2006) Granular and monolithic activated carbons from $\mathrm{KOH}$-activation of olive stones. Microporous Mesoporous Mater 92(1-3):64-70. https://doi.org/10.1016/j.micromeso.2006.01.002

Wang S, Soudi M, Li L, Zhu ZH (2006) Coal ash conversion into effective adsorbents for removal of heavy metals and dyes from wastewater. J Hazard Mater 133(1-3):243-251. https://doi. org/10.1016/j.jhazmat.2005.10.034

Wasewar KL, Atif M, Prasad B, Mishra IM (2008) Adsorption of zinc using tea factory waste: kinetics, equilibrium and thermodynamics. Clean-Soil, Air, Water. https://doi.org/10.1002/clen.20070 0139

Yagmur E, Ozmak M, Aktas Z (2008) A novel method for production of activated carbon from waste tea by chemical activation with microwave energy. Fuel. https://doi.org/10.1016/j. fuel.2008.05.005

Yang J, Qiu K (2011) Development of high surface area mesoporous activated carbons from herb residues. Chem Eng J 167(1):148154. https://doi.org/10.1016/j.cej.2010.12.013

Yue Q-Y, Wang W-Y, Gao B-Y, Xu X, Zhang J, Li Q (2010) Phosphate removal from aqueous solution by adsorption on modified giant reed. Water Environ Res 82:374-381

Zuorro A, Lavecchia R (2010) Adsorption of $\mathrm{Pb}$ (II) on spent leaves of green and black tea. Am J Appl Sci 7:153

Publisher's Note Springer Nature remains neutral with regard to jurisdictional claims in published maps and institutional affiliations. 